\title{
A synthesis of Mexican mammalogy in Therya: the first 10 years!
}

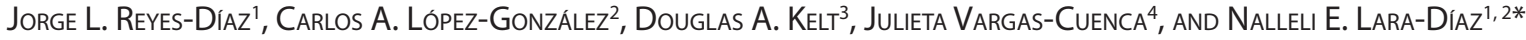 \\ ${ }^{1}$ Facultad de Ciencias, Universidad Nacional Autónoma de México. Av. Universidad 3000, C.P. 04510. Ciudad de México, México. \\ E-mail: jorgereyesdiaz46@gmail.com (JLR-D), lara.nalleli@gmail.com (NEL-D). \\ ${ }^{2}$ Laboratorio de Zoología, Facultad de Ciencias Naturales, Universidad Autónoma de Querétaro. Av. de las Ciencias s/n, C.P. \\ 76230, Santiago de Querétaro. Querétaro, México. E-mail: cats4mex@gmail.com (CAL-G). \\ ${ }^{3}$ Wildlife, Fish, and Conservation Biology, University of California, Davis. One Shields Avenue, Davies, CA 95616 U.S.A. E-mail: \\ dakelt@ucdavis.edu (DAK). \\ ${ }^{4}$ Colección Nacional de Mamíferos, Instituto de Biología, Universidad Nacional Autónoma de México. Circuito Zona Deportiva \\ s/n, Ciudad Universitaria, C.P. 04510. Ciudad de México, México. E- mail: jvargas@ib.unam.mx (JV-C). \\ *Corresponding author
}

Mammalogy as a discipline was pursued in México since the mid- $17^{\text {th }}$ century. However, Mexican researchers were involved primarily in the mid- $20^{\text {th }}$ century, when national scientific journals were established to emphasize research on mammals. In 2010, the Asociación Mexicana de Mastozoología, A. C., initiated the journal Therya. Therya has now completed its first decade of publication, and in this work, we analyze the articles and scientific notes published in Therya, focused on the studies of mammals in Mexican territory, including researchers and institutions, to describe the path that mammalogy has taken in recent years in México. This synthesis therefore serves as a frame of reference for future mammalogy studies. We compiled all papers published in Therya during the period 2010-2019. We built a database gathering information from these publications such as authors, institutions and states of origin, study areas, capture methods, topics and taxa studied. We excluded from the analyses research outside of México. We did a descriptive statistics analysis including mean, proportions, percentage and trends for each and all the sections. Therya has published 181 articles and 52 scientific notes on mammals distributed in México. The majority of authors and institutions were from México City. The states of southeastern México were the most used as a study area, particularly Oaxaca and Chiapas. The orders Carnivora and Cetartiodactyla were the most studied, mainly using indirect methods. Trapping methods were most commonly used for small mammals. The least studied orders were Eulipotyphla, Cingulata, and Pilosa. The most studied topics are ecology, diversity, conservation and distribution. Therya has become one of the most important journals about mammal research in México. Research in mammalogy, as reflected in the pages of Therya, is based in academic institutions with the metropolitan area of México City, reflecting the institutional infrastructure and age, and possibly institutional budgetary factors. The southeast portion of the country is well studied due to the existence of regional institutions, as well as to the concentration of high biodiversity. The least studied regions of México may be the result of a reduced number of research groups and social insecurity. Much research is focused on small mammals, making Sherman traps and mist nets the most used trapping methods; carnivores and cetartiodactyls are the most studied groups, using indirect study methods reducing study costs and effort. Ecology, diversity and distribution are the most studied topics, these studies allow the development of management plans.

En México la mastozoología tiene registro desde mediados del siglo XVII, con investigadores mexicanos involucrados desde mediados del siglo XX, siendo a finales de éste cuando se establecieron las primeras revistas nacionales con énfasis en mamíferos. En 2010 la Asociación Mexicana de Mastozoología, A. C., creó la revista científica Therya, que en 2019 completó su primera década de publicación. En este trabajo analizamos los artículos y notas científicas de Therya, enfocándonos en estudios en el territorio mexicano y los investigadores e instituciones que los realizan, para describir la trayectoria de la mastozoología en México en años recientes. Compilamos todas las publicaciones de la revista Therya entre 2010-2019. Construimos una base de datos recopilando la información de autores, instituciones y estados de procedencia, áreas de estudio, métodos de captura, temas y taxones. Excluimos las investigaciones que no incluyeran al territorio mexicano como área de estudio. Finalmente realizamos un análisis descriptivo incluyendo los promedios, proporciones, porcentajes y tendencias más representativas. Therya ha publicado 181 artículos y 52 notas científicas de mamíferos distribuidos en México. La mayoría de los autores e instituciones provienen de la Ciudad de México. El sureste de México, principalmente Oaxaca y Chiapas, es más frecuente como área de estudio. Los órdenes más estudiados fueron Carnivora y Cetartiodactila, principalmente por métodos indirectos. Métodos de trampeo se utilizaron frecuentemente para pequeños mamíferos. Eulipotyphla, Cingulata y Pilosa cuentan con pocos estudios. Los temas más estudiados son ecología, diversidad, conservación y distribución. Therya se ha pocisionado como una de las revistas más importantes sobre investigación de mamíferos en México. La mastozoología, como se refleja en Therya, se ha desarrollado principalmente por instituciones con mayor antigüedad, infraestructura y presupuesto institucional. El sureste del país es más estudiado debido a la existencia de instituciones regionales además de la alta concentración de biodiversidad. Las regiones menos estudiadas pueden relacionarse con la falta de grupos de investigación cercanos y la inseguridad. Muchas investigaciones se concentran en pequeños mamíferos, haciendo de las trampas Sherman y redes de niebla los métodos de trampeo más utilizados; carnívoros y cetartiodáctilos son los grupos más estudiados usando métodos de estudio indirecto que reducen los costos y esfuerzo de estudio. La ecología, diversidad y distribución son los temas más estudiados, que pueden apoyar el desarrollo de planes de manejo.

Keywords: Carnivora; Cetartiodactyla; journals; mammalogy; México; research trends; study topics. 


\section{Introduction}

Mammalogy is a discipline that has developed over many years in México. Since the mid- $17^{\text {th }}$ century, pioneering foreign researchers dedicated themselves to describing new species of mammals discovered within the borders of México (Baker 1991; Guevara-Chumacero et al. 2001; Ramírez-Pulido et al. 2017). Towards the end of the 19th century, one of the few Mexican researchers who stood out for his contributions to this field was the biologist and naturalist Alfonso L. Herrera, who published works on bats, primates, carnivores and some endemic species of México (Guevara-Chumacero et al. 2001). It was not until the middle of the $20^{\text {th }}$ century that mammalogy began to be notably developed and impacted by Mexican researchers, as Bernardo Villa, founding father of Mammalogy in México, gradually achieving a larger presence and relevance through Mexican universities and institutions (Guevara-Chumacero et al. 2001; Sánchez-Cordero and Medellín 2011; RamírezPulido et al. 2017). In 1984, the Asociación Mexicana de Mastozoología, A. C. (AMMAC), was established to bring together researchers, students and others with an interest in Mexican mammals, allowing improved coordination in the formulation of studies and research programs in mammalogy. The AMMAC has and continue to sponsor conferences where they could provide solutions to the problems, management policies and conservation of these animals and their ecosystems, regarding increasing threats from anthropogenic activities and the effects of climate change (Briones-Salas et al. 2014). These topics require constant research and dissemination.

Unfortunately, there are a few journals in México which focus solely on mammals. Acta Zoológica Mexicana and the Revista Mexicana de Biodiversidad, although they focus on fauna and biodiversity more generally, they include many articles about mammals. Additionally, the Revista Mexicana de Mastozoología has been published since 1995, with the version "Nueva era" from 2011 onwards (Institute of Biology 2020; Institute of Ecology 2020; INECOL A. C. 2020). This limited number of journals can cause a high demand to publish research and, due to the limited availability of reviewers for the number of articles requested, can generate substantial delays from peer-review to publication (Contreras et al. 2015). In addition to this, there is a certain fear among researchers from developing countries of not being cited in their own country, due either to antipathy, rejection of the national community or the possibility that peers will judge their work in a subjective way, especially when it comes to journals focused on a particular group (Ruiz-Argüelles 1999; Zárate 1999; Cicero-Sabido 2006). For this and other reasons, many researchers choose to publish in journals from other countries with international prestige, thereby avoiding this type of conflict, despite the high cost of publication of many journals. Consequently, the knowledge generated becomes less accessible for researchers and students in México and Latinamerica, in turn making this information less available to the general public.
The constant advancement of different technologies in the area of communication has facilitated the dissemination of information in electronic media, allowing the research generated over the years to reach interested people in almost any part of the world. This, together with the need for a journal specialized in mammalogy, spurred the AMMAC to create and publish the electronic journal Therya, the purpose of which is to freely disseminate research involving mammals from México and Latinamerica (SosaEscalante et al. 2014). Such a strategy has a high impact at the national and international level, particularly in recent years, where the number of publications, both articles and scientific notes, in English has increased in order to obtain a broader audience.

A decade has passed since the first issue of Therya was published, and the caliber of research published therein has led to recognition today as one of the mammalogy journals with a high impact factor (1.1; SCOPUS 2019), in addition to being considered a journal of international quality by the National Council of Science and Technology (CONACYT; AMMAC 2020). In this manuscript we compiled the Mexican research published in Therya during its first decade, with the aim of analyzing the trajectory of mammalian research in México, including the researchers and institutions that study mammals in Mexican territory, the most studied taxa, topics, methods and geographic scope. Thus, generating a reference baseline to assess gaps of knowledge on less studied aspects of mammalogy during recent years in México. However, future analyses of remaining papers that have been published in Therya from other countries are recomended to estimate the impact of the journal outside Mexican borders.

\section{Material and methods}

We searched all the volumes of the journal Therya between the years 2010-2019 (http://www.revistas-conacyt.unam. $\mathrm{mx} /$ therya/). We classified publications into articles and scientific notes according to the sections of the journal. Additionally, we considered nine publications as notes between 2010 to 2014 (Gallo-Reynoso and Leo Ortiz 2010; EscobedoCabrera and Lorenzo 2011; Gatica-Colima et al. 2011; Jiménez-Maldonado and López-González 2011; Valencia-Herverth and Valencia-Herverth 2012; Verona-Trejo et al. 2012; Hernández-Flores et al. 2013; Martínez-Coronel et al. 2013; Lira-Torres et al. 2014). Altough they were not in the scientific notes section, they have the structure, type of content, length (less than 10 pages), in addition to not being in-depth articles, as considered by Therya as of 2014.

Initially, we made a general description of full-length articles and scientific notes to determine their proportion in México and those in other countries of Latinamerica. From those, we selected those developed only within Mexican territory to analyze existing trends in mammalian research within México. We extracted the following information from each publication and built an Excel $^{\circledR}$ database: historical information (volume, number and year of 
publication), authors (name, sex [female, male], institution, country of origin), information about the research (title, topic, methods, states of study) and taxa data (order, family, species / subspecies, common name). We generated a database for all species and one for those taxa included in the Mexican endangered species list (SEMARNAT 2019) with their appearance in each year of publication of Therya, and analyzed their trends during 2010 to 2019 and a prediction for the year of 2020 to 2030 with a first-order Jackknife estimator and rarefaction curve, respectively (including species richness $S$ and confidence intervals $(I)$, conducted in the program EstimateS ver. 9.1.0 (Colwell 2013).

The publications, both articles and ascientific notes, were classified into 12 topics, including 11 proposed by Carleton et al. (1993) and reclassified by Guevara-Chumacero et al. (2001): food habits, anatomy and morphology, behavior, conservation, distribution, diseases and parasitism, ecology, miscellaneous (conference, echolocation, histology, body condition, historical review), physiology, reproduction, and taxonomy and phylogeny. To this we added the topic diversity, which included checklists, taxonomic inventories, and diversity analysis.

From the database, we describe the content of Therya in terms of: a) Number of publications, b) Authorship and Institutions, c) State study areas, d) Methods used, e) Taxa studied, and f) Topics studied. We described the results using sample size ( $n$ ), frequency (\%), proportion, mean, and standard deviation (SD). We included the number of fulllength articles and notes in each subsection.

\section{Results}

Publications. From its origin until 2019, Therya has published 10 volumes consisting of three issues each; these volumes included 342 publications, of which 261 are articles (76.3\%) and 81 are scientific notes (23.7\%). On average, there were $34.60 \pm 10.74$ publications per year, with the lowest number of publications $(n=17)$ in 2010, and the highest $(n=45)$ in 2013 (Figure 1). During the first three years of publication (2010 - 2012), studies of foreign Latinamerican localities (including articles and notes) were minimally represented in the journal (zero to two publications per year). From 2013 onwards, however, these studies achieved higher frequency, with a mean of $15.71 \pm 3.2$ publications per year (range, 10 to 20). Of the total publications in Therya, published 181 articles (69.35\%) and 52 scientific notes (64.20\%) reported on studies performed in México, with the the lowest number of articles in 2018 $(n=12)$ and the highest number $(n=32)$ in 2013. Only two or three scientific notes were published each year during the first four years of the journal. However, as of 2014, publication of notes increased on average to seven per year, reaching the highest number in $2018(n=8)$. For all subsequents analyses, we focuse solely on the 233 publications pertaining to Mexican localities (http://www.revistasconacyt.unam.mx/therya/).

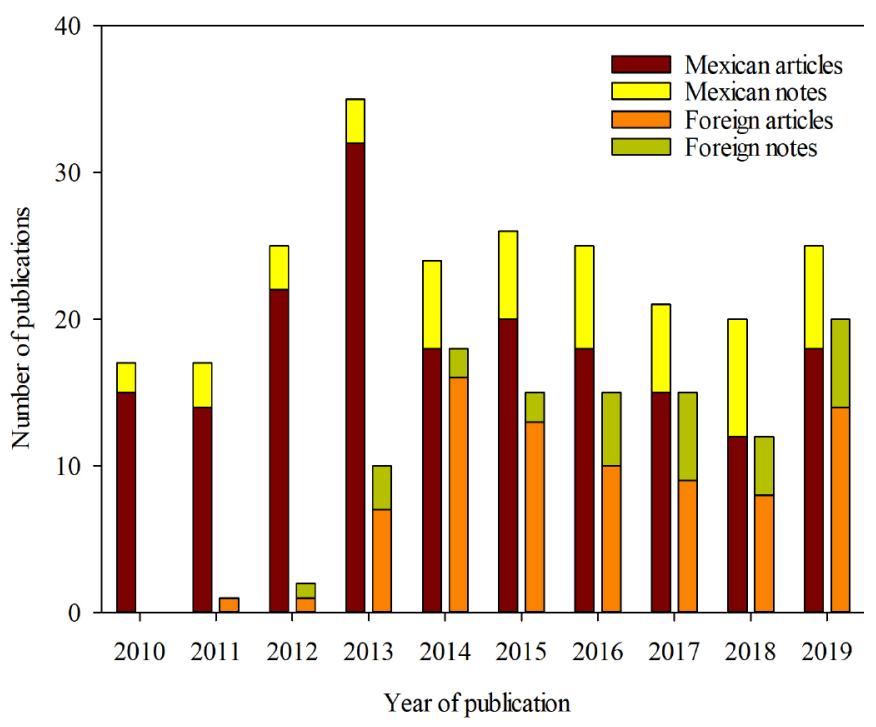

Figure 1. Number of national and foreign publications (articles and scientific notes) in Therya in the period 2010 to 2019.

Authors and Institutions. These 233 publications were published by 589 authors, with an overall sex ratio of 1:1.58 (female: male); the most equitable participation was in 2010 $(1: 1.2, n=55$ authors) and the most unequal in 2015 (1:3.23, $n$ $=110$ authors). On average, there were $3.89 \pm 3.46$ SD authors per publication, with a range of 1 to 48 authors. Ninety-four percent of the researchers have participated in a range of one to three publications, $~ 5 \%$ have between four and nine, while the remaining $1 \%$ are represented by researchers with 10 or more publications: these include Consuelo Lorenzo ( $n=16)$, Juan Pablo Gallo-Reynoso $(n=13)$, Sonia GallinaTessaro $(n=12)$, Fernando A. Cervantes $(n=11)$, and Miguel Ángel Briones-Salas and Salvador Mandujano ( $n=10$ each).

Most of the authors and co-authors (98.13\%) have institutional affiliations (overall, representing 110 institutions), and 27 authors report an affiliation to more than one institution. Eleven authors and co-authors are independent and do not belong to an institution; one of these is a member of an ejido. Sixteen institutions are represented by 10 to 82 authors (or co-authors) each (Figure 2); all other institutions are represented by 1 to 8 authors. In general, the institutions with the highest number of assigned authors also have a greater number of collaborations, with the exception of the Centro de Investigación en Alimentación y Desarrollo A. C. and the Universidad de Ciencias y Artes de Chiapas, which have fewer than 10 assigned authors but 13 and 11 publications, respectively (Figure 2).

Education and research institutions make up $62 \%$ of the total institutions that have collaborated in the journal's publications, followed by non-governamental institutions (27.3\%). Government institutions constitute less than $10 \%$, with the Comisión Nacional de Áreas Naturales Protegidas (CONANP) and the Instituto Nacional de Antropología e Historia (INAH) collaborating on the greatest number of publications (four each). Only three institutions are private or commercial (Especialidades en Diagnóstico S. A. de C.V., Desarrollos, Proyectos y Gestoría Ambiental S. A. de C. V., and Compañía Minera Cuzcatlán). 


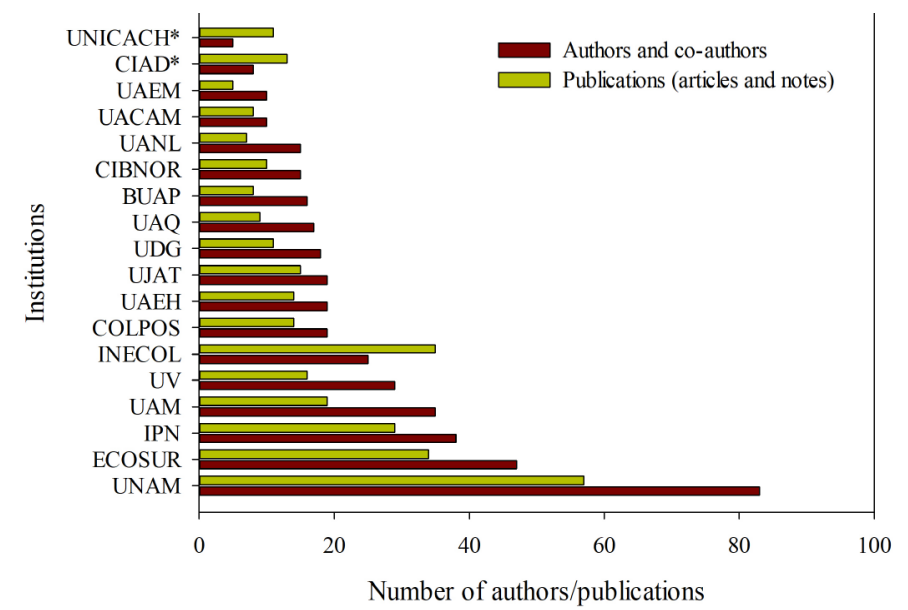

Figure 2. Institutions with the highest number of ascribed authors and collaboration in publications in Therya. UNAM - Universidad Nacional Autónoma de México, ECOSUR - El Colegio de la Frontera Sur, IPN - Instituto Politécnico Nacional, UAM - Universidad Autónoma Metropolitana, UV - Universidad Veracruzana, INECOL - Instituto de Ecología A. C., UJAT - Universidad Juárez Autónoma de Tabasco, COLPOS - Colegio de Postgraduados, UAEH - Universidad Autónoma del Estado de Hidalgo, UDG - Universidad de Guadalajara, UAQ - Universidad Autónoma de Querétaro, BUAP - Benemérita Universidad Autónoma de Puebla, CIBNOR - Centro de Investigaciones Biológicas del Noroeste, S. C., UANL - Universidad Autónoma de Nuevo León, UACAM - Universidad Autónoma de Campeche, UAEM - Universidad Autónoma del Estado de Morelos, CIAD - Centro de Investigación en Alimentación y Desarrollo, A. C., UNICACH - Universidad de Ciencias y Artes de Chiapas. An asterisk $\left(^{*}\right)$ denotes institutions with less than 10 authors but more than 10 publications.

Of those publications done in Mexican territory, $22.3 \%$ of the institutions are foreign, from a total of 110 documented institutions. The range of participation of foreign institutions was from one to six publications. The contribution of foreign institutions in order of importance came from New México State University and Texas A\&M University, both in the United States. Additionally, other institutions from the United States, United Kingdom, Colombia, Venezuela, Brazil, Canada, Guatemala, New Zealand, Panama, Perú and Sweden have also collaborated in Therya publications.

Mexican institutions represented in Therya publications are distributed across 27 states, mainly México City ( $n=16$ institutions), Oaxaca $(n=9)$, Chiapas, Puebla ( $n=$ 7 each), and Campeche $(n=6)$. Only five states are not represented in Therya author institutions; these are Aguascalientes, Colima, Guerrero, Nayarit, and Sinaloa. The most represented institutions at the state level are the Universidad Nacional Autónoma de México in five states (Ciudad de México, Estado de México, Michoacán, Morelos, and Veracruz), the Instituto Politécnico Nacional (Ciudad de México, Durango, Oaxaca, and Yucatán) and the Colegio de Posgraduados (Campeche, Estado de México, Puebla, and San Luis Potosí), in four states, respectively. El Colegio de la Frontera Sur (Campeche, Chiapas, and Quintana Roo) and CONANP (Campeche, Chiapas, and Sonora) are represented in three states each.

Study areas. Research published in Therya ( $n=157$ articles, 49 notes) is distributed across 31 of the 32 states of the Mexican Republic (Figure 3). The majority of these publications ( $85 \%$ ) represent work conducted in a single state, with the remainder considering 2 to 11 states as the study area. The most well-represented states within the publications were Oaxaca (16.4\%), Veracruz (7.3\%), Puebla (6.5\%), and
Chiapas (5.5 \%; Figure 3). The states with the fewest studies include Baja California Sur, Zacatecas, Michoacán, México City and Aguascalientes, each with two to four publications. Nayarit is represented by only one scientific article (ViloriaGómora and Medrano-González 2015), and Guerrero with a single scientific note (Martínez-Coronel et al. 2013). Sinaloa was not included as a study area in any publication of the journal, article or note, until 2019 (Figure 3). Some publications do not specify a given state in their study area description $(n=27)$. Of these, five publications were reviews.

Methods used. Publications in Therya used between one and five methods for the study of mammals each, with the majority (55.5 \%) using a single method. Among the least used are the application of forms (e.g., questionnaires, surveys, and interviews) and telemetry, recorded in 11 publications each, as well as the collection and use of corpses $(n=8)$ and bioacoustics ( $n=5$; Figure 4 a). The most common methods in the publications are some form of trapping / capture technique, which was included in more than a third of all publications $(n=83)$, search and use of spoor $(n=54)$, photo trapping $(n=53)$, and reviews of literature to obtain data ( $n=47$; Figure 4 a). Among trapping / capture methods, mist nets and Sherman traps predominate, appearing in 27 and 26 publications, respectively, followed by Pitfall ( $n=10$ publications) and Tomahawk traps ( $n=7$ publications); other trapping techniques appear only in three or fewer publications (Figure 4 b). In general, 25

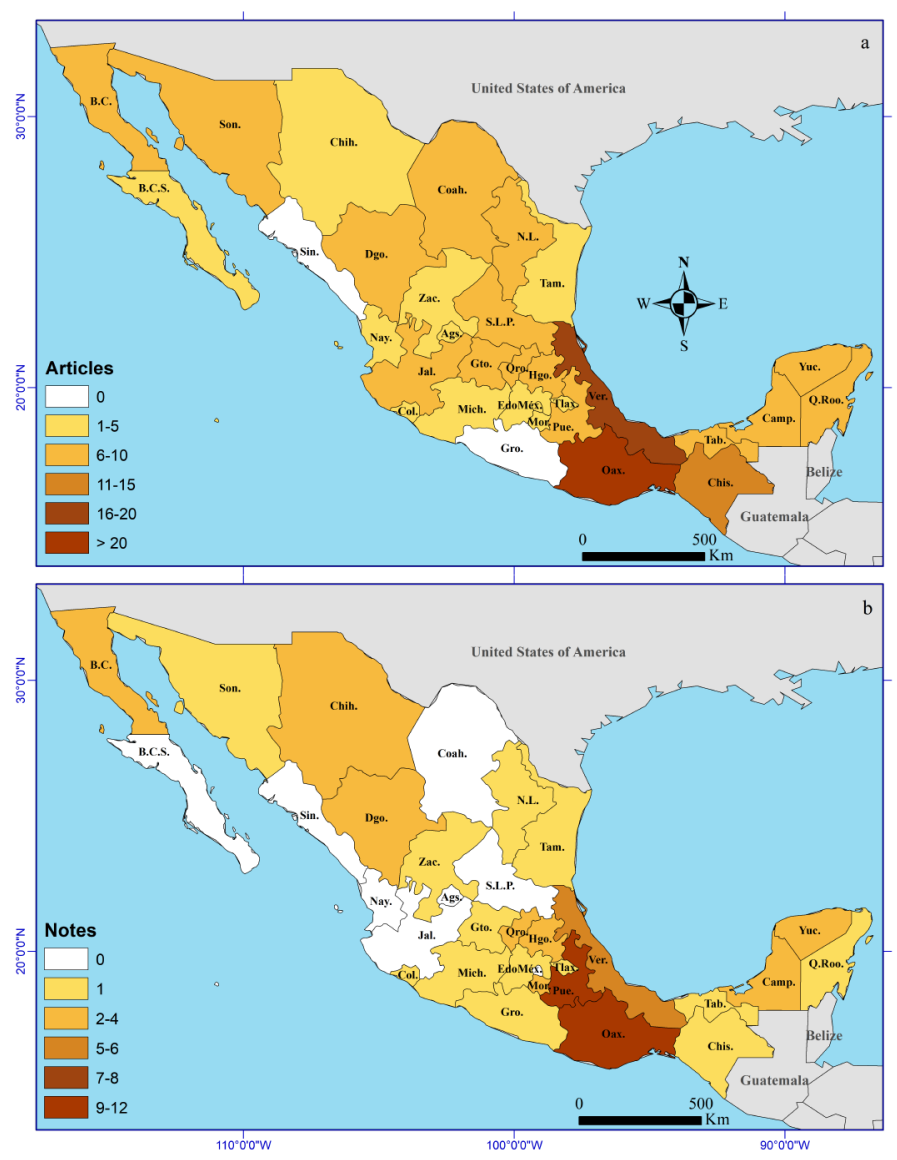

Figure 3. Distribution of publications (a) Number of Articles, b) Number of Notes) by Mexican state used as the study area. 
direct sampling methods were used, of which 16 occur during Therya's first year of publication. In the following years only one or two new methods are added per year, all of them with a low frequency of appearance in the articles (i.e., snares, noose, drop nets, manual net, fishing net, funnel trap, lethal trapping, and snap trapping). Unspecified trapping is presented in three publications.

Taxa studied. Across all publications, 376 species studied come from all orders of mammals known to occur in Mexican territory (Ceballos 2014; Ramírez-Pulido et al. 2014). This includes six domestic / feral species (Bos taurus, B. indicus, Canis lupus familiaris, Felis silvestris catus, Mus musculus, Rattus rattus, and Sus scrofa). In 202 publications $(86.8 \%)$, research on species from a single order are addressed, while 27 publications (11.5\%) included two or more orders; four publications (1.7\%) addressed topics on mammals in general (Lorenzo et al. 2012; Briones-Salas et al. 2014; Ramírez-Pulido et al. 2017; Mandujano 2019). The most frequently studied orders in both articles and scientific notes were Carnivora (23.8\%), Cetartiodactyla (16.2\%), Rodentia (15.3\%) and Chiroptera (12.9\%; Figure $4 \mathrm{c}$ ), while the least studied orders were Primates (2.7\%), Pilosa (1.9\%) and Sirenia (1 \%; Figure $4 \mathrm{c}$ ).

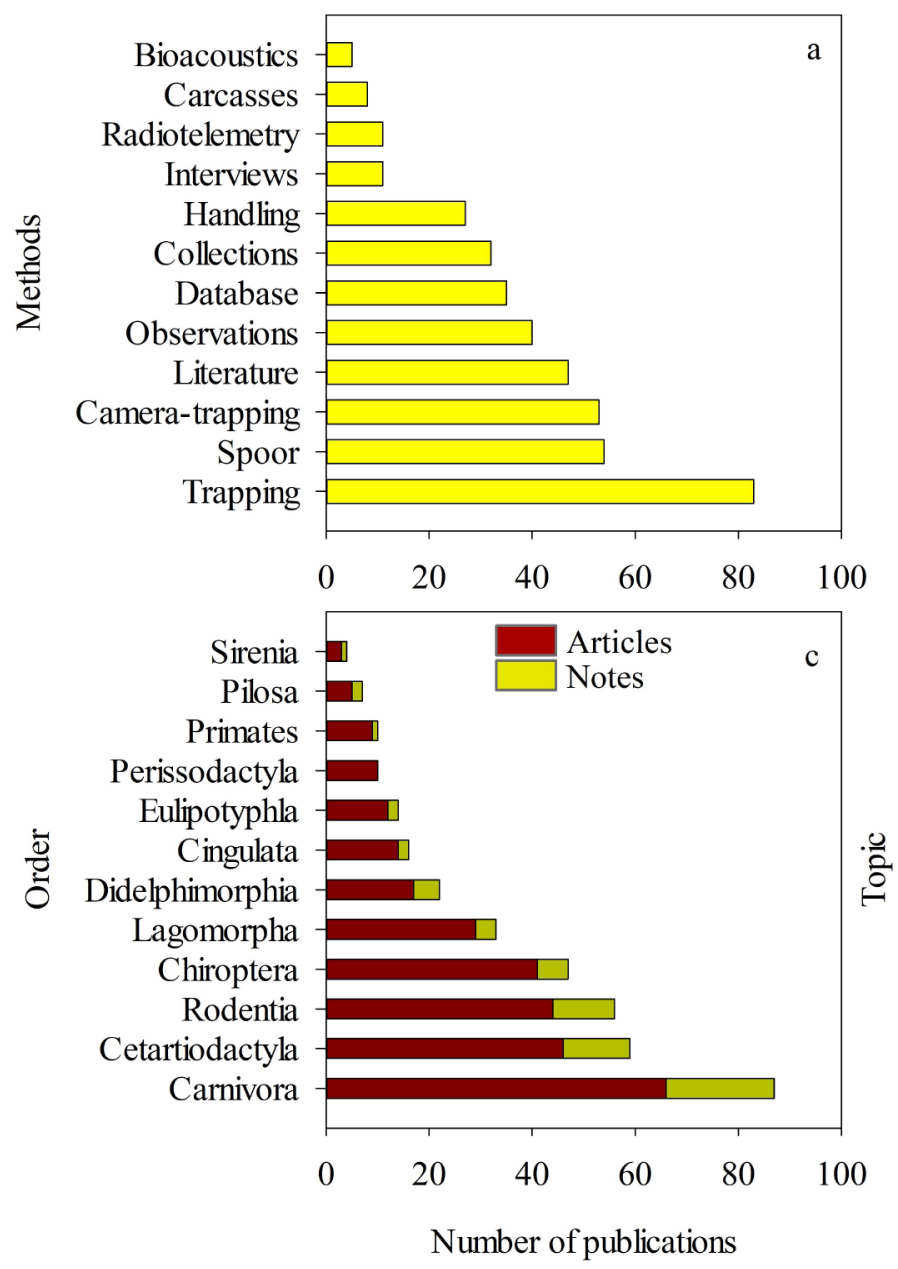

Publications on Carnivora and Rodentia span 27 and 26 states of the Mexican Republic, respectively, followed by Cetartiodactyla and Chiroptera in 23 and 20 states, respectively. The publications that include the orders Cingulata, Eulipotyphla, Primates, Pilosa and Sirenia occur in a range between two to nine states of México. The states of Oaxaca, Chiapas, Tabasco and Yucatán are represented in publications that address 10 or 11 orders of mammals (Table 1 ).

Across all publications, 164 (70.4 \%) focused on 83 species individually, while the remaining 69 works (29.6\%) addressed issues related to diversity and abundance of mammals in general or of some particular order, encompassing a total of 365 species. Most single-taxon publications $(73.5 \%)$ were scientific articles; the most common taxa studied were the white-tailed deer (Odocoileus virginianus; $n=14$ articles), the Neotropical otter (Lontra longicaudis; $n=13$ ) and the Central American tapir (Tapirella bairdii; $n=10$ ). There are no scientific articles investigating individual species of the orders Cingulata and Pilosa (Appendix 1). Scientific notes addressed 41 species $(49.4 \%$ of the total species studied individually), of which the ocelot (Leopardus pardalis; $n=5$ ), the American black bear (Ursus americanus; $n=3$ ), the kit fox (Vulpes macrotis; $n=2$ ), the Cave myotis

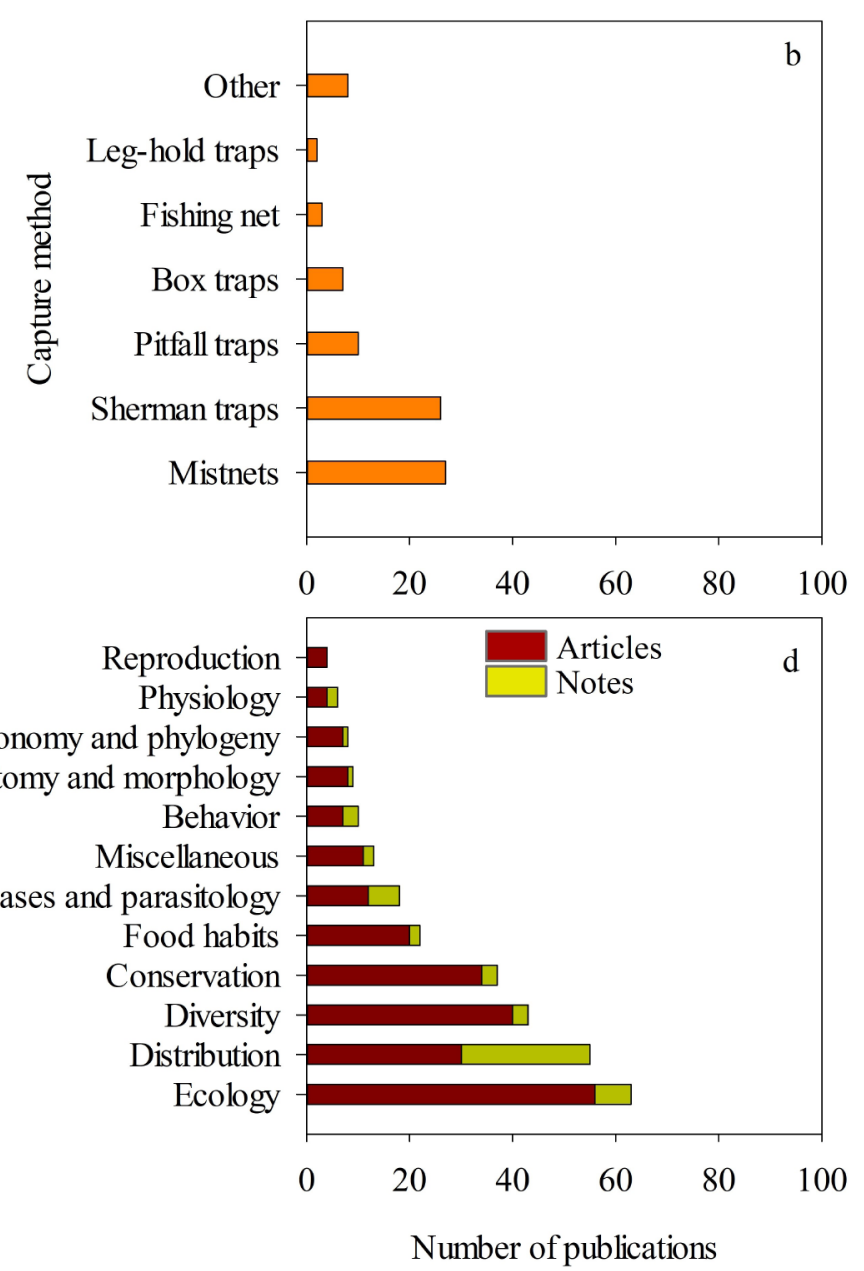

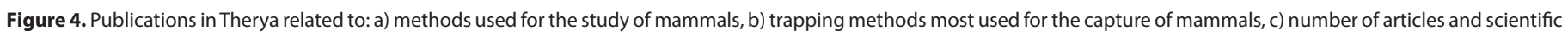
notes by order of Mexican mammals, and d) number of articles and scientific notes by topic of study. 
Table 1. Number of publications (articles and scientific notes) by Mexican state used as study area and order of mammal studied. Car = Carnivora; Cet = Cetartiodactyla; Chi = Chiroptera; Did = Didelphimorphia; Eul = Eulipotyphla; Lag = Lagomorpha; Per = Perissodactyla; Pil $=$ Pilose $;$ Pri $=$ Primates; Rod $=$ Rodentia $;$ Sir $=$ Sirenia

\begin{tabular}{|c|c|c|c|c|c|c|c|c|c|c|c|c|c|}
\hline \multirow{2}{*}{ State } & \multicolumn{12}{|c|}{ Order } & \multirow{2}{*}{$\begin{array}{c}\text { Total } \\
\text { orders }\end{array}$} \\
\hline & 心 & $\stackrel{\Perp}{U}$ & $\bar{u}$ & $\tilde{\varepsilon}$ & 흠 & $\overline{\bar{u}}$ & ర్తా & ¿̀ & $\bar{a}$ & $\overline{\mathbf{a}}$ & $\underset{\propto}{\not}$ & $\vdots$ & \\
\hline Aguascalientes & & & & & & & & & & & 2 & & 1 \\
\hline Baja California & 3 & 4 & 1 & & & & & & & & 1 & & 4 \\
\hline Baja California Sur & & 1 & & & & & 2 & & & & 1 & & 3 \\
\hline Campeche & 2 & 5 & 2 & & & & & 2 & & & 2 & & 5 \\
\hline Chiapas & 4 & 4 & 4 & 2 & 3 & 3 & 2 & 2 & 1 & 1 & 7 & & 11 \\
\hline Chihuahua & 3 & 2 & 1 & & & & 2 & & & & 2 & & 5 \\
\hline Ciudad de México & 1 & & & & & & & & & & 1 & & 2 \\
\hline Coahuila & 2 & 6 & 3 & 1 & 1 & & 3 & & & & 3 & & 7 \\
\hline Colima & 1 & 2 & 1 & & & & & & & & 1 & & 4 \\
\hline Durango & 5 & 3 & 1 & & & & 2 & & & & 3 & & 5 \\
\hline Estado de México & 1 & & & & & & & & & & 4 & & 2 \\
\hline Guerrero & & & & & & & & & & & 1 & & 1 \\
\hline Guanajuato & 4 & 1 & 3 & 1 & 1 & 1 & 1 & & & & 2 & & 8 \\
\hline Hidalgo & 7 & 2 & 2 & & 1 & 1 & 1 & & 1 & & 4 & & 8 \\
\hline Jalisco & 2 & 1 & 3 & 1 & 1 & 1 & 1 & & & & 4 & & 8 \\
\hline Michoacán & 2 & 1 & & & & & & & & & & & 2 \\
\hline Morelos & 1 & 2 & 2 & & & & 1 & & & & & & 2 \\
\hline Nayarit & & 1 & & & & & & & & & & & 1 \\
\hline Nuevo León & 2 & 3 & 1 & & & & & & & & 1 & & 4 \\
\hline Oaxaca & 18 & 17 & 13 & 7 & 7 & 3 & 13 & 2 & 3 & 4 & 10 & & 11 \\
\hline Puebla & 10 & 5 & 2 & 2 & 2 & 2 & 1 & 1 & & & 4 & & 9 \\
\hline Querétaro & 5 & & & & 1 & & & & & & 4 & & 3 \\
\hline Quintana Roo & 3 & 2 & & & & & & 1 & & & 2 & & 4 \\
\hline San Luis Potosí & 6 & 1 & 1 & & 1 & & 1 & & & & 3 & & 6 \\
\hline Sinaloa & & & & & & & & & & & & & 0 \\
\hline Sonora & 5 & 3 & 1 & & & & & & & & & & 3 \\
\hline Tabasco & 1 & 2 & 4 & 1 & 1 & & 1 & & 1 & 3 & 1 & 3 & 10 \\
\hline Tamaulipas & 5 & & & & & & & & & & & & 5 \\
\hline Tlaxcala & 1 & & 2 & 1 & 1 & 2 & 2 & & & & 2 & & 7 \\
\hline Veracruz & 5 & 5 & 1 & & 1 & 1 & & 1 & & 1 & 7 & & 8 \\
\hline Yucatán & 1 & 3 & 1 & 1 & 1 & & 1 & 1 & & 1 & 4 & 1 & 10 \\
\hline Zacatecas & 2 & & & & & & & & & & 2 & & 2 \\
\hline Total states & 27 & 23 & 20 & 9 & 13 & 8 & 15 & 7 & 4 & 5 & 26 & 2 & \\
\hline
\end{tabular}

(Myotis velifer; $n=2$ ) and the Mexican porcupine (Coendou mexicanus; $n=2$ ) were most frequently represented. Pilosa was represented by a single publication (Appendix 1).

A total of 369 species have been addressed in Therya in its first decade (Figure 5). The expected richness according to the first-order Jackknife estimator is 464 species ( $\pm 27 \mathrm{SD}$ ), suggesting that Therya has documented only $80 \%$ of the expected species richness. Rarefaction indicates that continued accumulation of new species in Therya will be slow, reaching approximately 434 species $(\mathrm{Cl} 404$ 464) in the following 10 years (Figure 5). Considering the number of species reported for México $(S=564$; Sánchez-
Cordero et al. 2014), the species currently included represent $65 \%$, and the species estimated for 2030 will be $70.6 \%$ of the richness of mammals for the country (Figure 5).

Twenty-one wild species have been reported in both articles and notes ( $n=271$ publications), generally as part of diversity inventories ( $66.4 \%$ of the studies). We considered 12 of these species to occur commonly (10 or more occurrences; Figure 6). The majority of species in Therya $(S=271$ species) are mentioned only in diversity studies, and most of these $(S=118$ ) belong to the order Chiroptera (Figure 6).

Over one-quarter $(27.5 \%)$ of the species in Therya publications ( $S=103$ species) are listed under some risk category by the Mexican government (e. g., Norma Oficial Mexicana NOM-059; SEMARNAT 1994, 2010, 2015); this includes 33 species listed as threatened, 45 species subjected to special protection and 25 species in danger of extinction. Notably, this includes 33 endemic species to México. The species listed in the NOM-059-SEMARNAT-2010 belong to the orders Carnivora, Chiroptera, Eulipotyphla, Lagomorpha and Rodentia (Figure 7; Appendix 1), and represent $75 \%$ of the species expected in the first 10 years according to the first order Jackknife estimator (136 species \pm 12 SD). Rarefaction suggests that a total of 120 species at risk ( $\mathrm{Cl} 107$ - 134 species) is estimated to be represented in Therya by its 20th year of publication (Figure 5). Species at risk in Therya represent approximately $44 \%$ of species at risk nationally (SEMARNAT 2019; Figure 5), with an expected increase to $51 \%$ in the next 10 years.

Topics studied. Most publications in Therya $(77.7 \%)$ focused on only one of the 12 topical categories, followed by $20.6 \%$ that addressed two topics and a minor fraction $(1.7 \%)$ that addressed three topics. Among scientific articles, Ecology (24\%), Diversity (17.2\%) and Conservation (14.6\%) stand out, with lesser representation by Anatomy

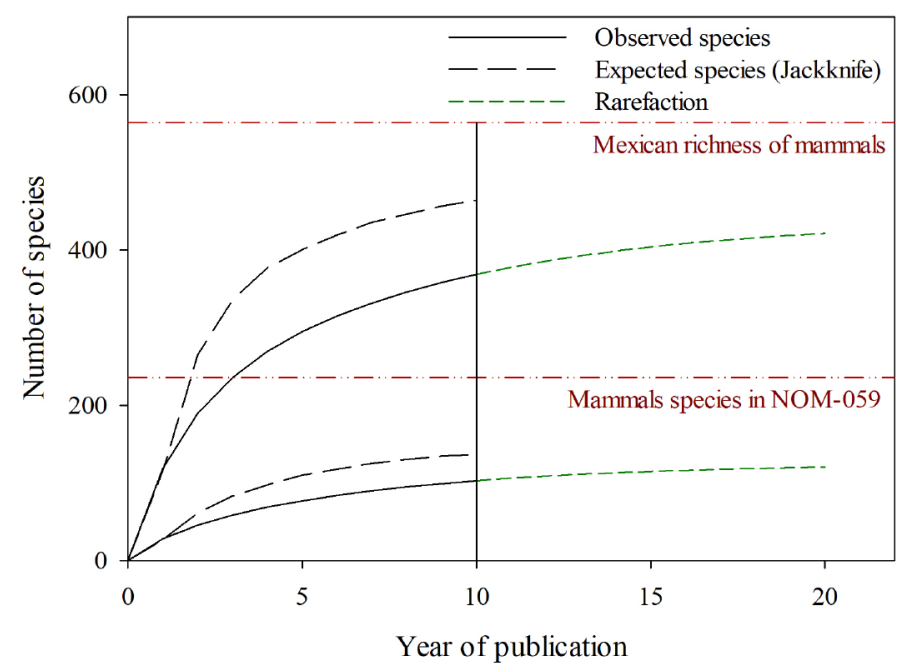

Figure 5. Number of species mammals represented in both articles and notes published in Therya in its first decade (observed and Jackknife estimated) and predicted by rarefaction over its second decade. Upper lines represent all species in the first decade $\left(S_{\text {obs }}=369, S_{\text {exp }}=464 \pm 27\right)$ or predicted by $2020(S=434, C l=404-464)$. Lower lines represent all species in the first decade $\left(S_{\text {obs }}=103, S_{\text {exp }}=136 \pm 12\right)$ or predicted by $2020(S=120$, $\mathrm{Cl}=104-134)$. Horizontal dashed lines indicate known richness of mammals in Mexico (S $=564)$ and in NOM-059-SEMARNAT-2010 $(S=236)$. 
and Morphology, Behavior, Taxonomy, and Phylogeny, Physiology and Reproduction, which together represent $12.9 \%$ of articles. Among scientific notes, the most studied topics were Distribution (45.5\%), Ecology (12.7\%), and Diseases and Parasitism (10.9\%; Figure $4 \mathrm{~d}$, Table 2).

\section{Discussion and conclusions}

Therya has published for a decade at this point, and is among the principal mammal-oriented publications in México, exceeding in number of publications journals such as Acta Zoológica Mexicana (with 175 publications until 2016), Revista Mexicana de Mastozoología (119 publications), or Revista Mexicana de Biodiversidad (101 publications), which have existed over a longer period (since 1955, 1995, and 2005, respectively; Ramírez-Pulido et al. 2017).

The international option of Therya as a journal for publication, particularly as of 2013, influenced a gradual increase in the number of publications with a broader geographical scope, equaling and even exceeding the number of Mexican scientific articles in Therya some years. In addition to this, $\sim 14 \%$ of national publications are authored or coauthored by foreign researchers, most of them from institutions in the United States, similar to what was reported by Arizmendi et al. (2015) in Revista Mexicana de Biodiversidad. Thus, the historical relationship with educational institutions and journals in that country is maintained through different degrees of collaboration (Ramírez-Pulido et al. 2017). Therya's process of internationalization allows to establish valuable relationships that strengthen the knowledge of Latinamerican mammals worldwideas it has occurred through the history of the Journal of Mammalogy (Álvarez-Castañeda et al. 2019).

Mammalogy, like the vast majority of disciplines and sciences in México and Worldwide, was historically a male-dominated endeavor (García-Angélica et al. 2012), so authorship by Mexican female researchers was uncommon until recently. As in other areas of science, however, this has changed as gender stigmas have been eliminated, and women have been recognized for their contributions in mammalogy (Lorenzo et al. 2013). Although women

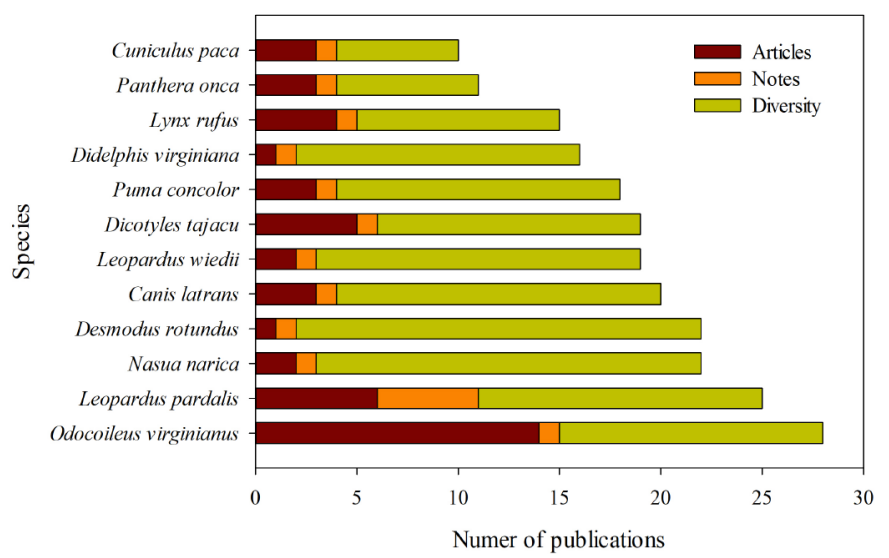

Figure 6. Species with the highest number of mentions in the publications of Therya. "Articles" and "Notes" includes all topics exept studies focusing on Diversity; “Diversity" includes both publication types, articles and scientific notes.
Table 2. Number of publications (articles and scientific notes) with two study topics; the number of posts is indicated under the diagonal. Topics: Food = Food habits; Ana / Mor = Anatomy and Morphology; Beh = Behavior $;$ Cons = Conservation; Dist = Distribution; Div = Diversity; Ecol = Ecology; DisP = Diseases and Parasitism; Phy = Physiology; Rep $=$ Reproduction; Tax = Taxonomy and Phylogeny.

\begin{tabular}{|c|c|c|c|c|c|c|c|c|c|c|c|}
\hline Topics & $\begin{array}{l}\text { 므 } \\
\text { 이 }\end{array}$ & 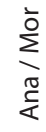 & $\frac{\square}{\otimes}$ & $\stackrel{\simeq}{0}$ & $\frac{\pi}{0}$ & a & 엄 & $\frac{n}{0}$ & 즘 & $\stackrel{\circ}{\propto}$ & $\stackrel{\times}{\stackrel{x}{\circ}}$ \\
\hline \multicolumn{12}{|l|}{ Food } \\
\hline \multicolumn{12}{|c|}{ Ana / Mor } \\
\hline Beh & 1 & & & & & & & & & & \\
\hline Cons & 3 & & & & & & & & & & \\
\hline Dist & 1 & & & 8 & & & & & & & \\
\hline Div & & & & 6 & 1 & & & & & & \\
\hline Ecol & 3 & 1 & 5 & 7 & 3 & 1 & & & & & \\
\hline DisP & & & & 1 & & & & & & & \\
\hline Phy & & & 1 & & & & & 1 & & & \\
\hline Rep & & & & & & & 1 & & 1 & & \\
\hline Tax & & & 1 & & & 2 & & & & & \\
\hline
\end{tabular}

have contributed to Therya from its inception, their contributions have increased over the years; a similar trend has been observed in congresses organized by the AMMAC (Lorenzo et al. 2014). In Therya the temporal trend in male authorship has been higher than that for female authors in each year, with a sex ratio range of 1:1.2 to 1:32 (female: male). This reflects similar trends globally, for example, Salerno et al. (2020) noted that in ecological and zoological journals, female authorship has increased only marginally in the last two decades (up to $31 \%$ ), and there is a tendency for research groups led by men to publish with fewer coauthors. Although Therya is a relatively young journal, female participation, either as reviewers, editors or authors, includes two women within the group of six researchers with the highest number of publications (Consuelo Lorenzo and Sonia Gallina-Tessaro).

At the institutional level, UNAM has the largest number of authors, co-authors and publications in Therya, similarly to its contribution to other journals such as Journal of Mammalogy (Álvarez-Castañeda et al. 2019). Although in Therya, institutions such as ECOSUR, IPN, UAM and INECOL also have a significant number of publications and attached researchers. These institutions have education and research centers in more than one state of the country; for example, México City includes UNAM, UAM and IPN, older academic institutions that also receive the largest federal or state budget for higher education (DOF 2019). This allows these institutions to maintain a stable staff of researchers, as well as the facilities and equipment necessary to support students and therefore greater visibility in Mexican mammalian research.

At the level of federal entities, México City has been a key center of training for Mexican mammalogists; this indicates a trend of centralization of mammal research in the country (Guevara-Chumacero et al. 2001). Additionally, some of the 
most important mammalogy collections are housed in the country's capital (Lorenzo et al. 2012), which greatly facilitates the acquisition of some types of data without requiring field trips, leading to a large number of publications related to this information. Consequently, the institutions that safeguard mammalogy collections (UNAM, UAM and IPN) have sufficient resources to initiate and conduct new studies (Briones-Salas et al. 2014; Arechavala-Vargas and Sánchez-Cervantes 2017). It is clear that state funded institutions of higher education do not publish in the same way as federally funded institutions of higher education, which reflects the budgetary disparity of these entities. This observation suggests that greater support to state funded institutions of higher education might promote research in those sites and areas least explored by mammalogists (Arechavala-Vargas 2011; Arechavala-Vargas and SánchezCervantes 2017; Mendoza-Rojas 2019).

Historically, the states of Veracruz, Sonora, Baja California, Oaxaca, Chiapas, Jalisco and Puebla were the dominant foci of mammalian research in México (Guevara-Chumacero et al. 2001; Briones-Salas et al. 2014; Lorenzo et al. 2014). In Therya, studies in the southern region persist (Oaxaca, Chiapas and Campeche), but the northwest region has been replaced by studies based in the eastern parts of the country (Veracruz, Puebla and Hidalgo). Oaxaca, Chiapas and Veracruz are the states with the highest biodiversity recorded in Mexican territory (SEMARNAT 2012), which makes them attractive for study (Ramírez-Pulido and Castro-Campillo 1993); they also have important institutions for the study and conservation of fauna and its ecosystems (GuevaraChumacero et al. 2001; Briones-Salas et al. 2014; Lorenzo et al. 2014). Amid the least represented states for field studies are Aguascalientes, Nayarit, Zacatecas and Sinaloa (GuevaraChumacero et al. 2001; Briones-Salas et al. 2014). In Therya, few or no publications have focused on mammals on those States, and coupled with Baja California Sur, Guerrero, and Michoacán, comprising 5.5\% of the national studies in the journal. The reduced number of studies likely relates to a lack of research groups and social insecurity.

Physical capture was the most widely used approach in the journal's publications in the last 10 years. Such methods generally are essential for studies on bats and rodents, orders that represent little more than $90 \%$ of the specimens collected and deposited in scientific collections in México (Lorenzo et al. 2012) as well as being the most diverse and abundant groups in the world (Sánchez-Cordero et al. 2014; Mammal Diversity Database 2020). Both orders comprise between $35 \%$ and $43 \%$ of the studies in Therya.

Carnivora and Cetartiodactyla were included in more publications, representing medium to large animals whose study is challenging, both ecologically (e. g., elusive animals; Powell and Proulx 2003; Nielsen et al. 2012; Proulx et al. 2012) and economically (e. g., high cost of trapping and follow-up; Hoffmann et al. 2010; Proulx et al. 2012). For this reason, indirect study methods are more widely represented for these larger taxa, highlighting the search and

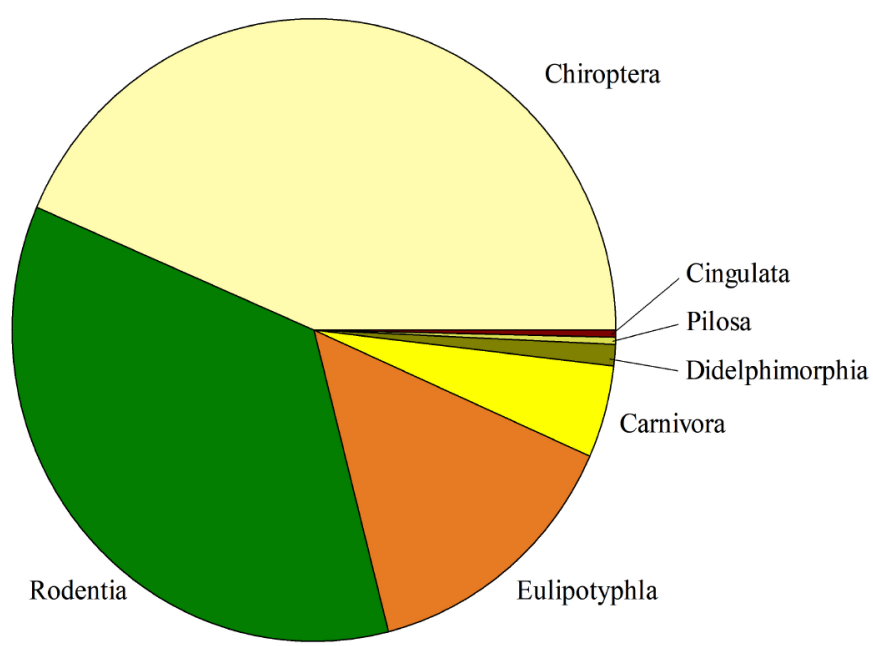

Figure 7. Proportional representation of mammalian orders within NOM059-SEMARNAT-2010 (SEMARNAT 2019).

use of spoor, camera trapping and the literature review, greatly reducing costs and limiting the effort to study these species (Putman 1984; Tomas and Miranda 2003; GuzmánLenis and Camargo-Sanabria 2004; Lyra-Jorge et al. 2008; Hoffmann et al. 2010).

The cost associated with the use of mist nets, Sherman traps and camera traps are high and increases with the loss of equipment as well as vandalism and a lack of respect for property by local people (Meek et al. 2019). However, the high representation of these approaches in the journal's research may reflect an investment aimed at a greater efficiency in data acquisition; additionally, it has become easier to obtain specialized equipment in México that was in the past (Díaz-Pulido and Payán 2012; García-Grajales and Buenrostro-Silva 2019).

It should be noted that the journal's publications do not include use of new technologies (e. g., drones, environmental DNA; Harper et al. 2019; Leempoel et al. 2020; Schroeder et al. 2020), or some methods that have historically shown their effectiveness for detection of mammals (e. g., use of dogs; Dahlgren et al. 2012; Webster and Beasley 2019). However, the efficiency of these approaches is important for detection of species that traditional methods generally miss (Harper et al. 2019; Leempoel et al. 2020), helping to complete the fauna and diversity studies that are abundant in Therya. The incorporation of new methods in Therya is slow, but their use in conjunction with traditional methods could bring innovation to mammalian studies in México.

We believe that the taxonomic representation of Mexican mammal diversity in Therya is adequate considering it's only 10 years old. This representation may vary depending on the addition of new species or taxonomic changes (e.g., Arcangeli et al. 2018; Álvarez-Castañeda et al. 2019; Camargo and Álvarez-Castañeda 2020; León-Tapia et al. 2020). Consecuently, it is of interest to continue with taxonomic descriptions, which can be supported through genetics studies (Guevara et al. 2014). As well as generating updated and complete lists of the species richness of mammals in México. However, the suite of species addressed includes 
a few that are of particular interest to some researchers, or particularly easy to study, and consequently they attain undue attention in terms of number of publications. The complement to this, however, is that the species that have not been included in Therya or are very poorly represented; as these constitute more than $30 \%$ of the Mexican diversity of mammals (Figure 5), this lack of attention is an important call for action to remedy these taxonomic gaps.

The species given the greatest attention include the white-tailed deer, the Neotropical otter and the Central American tapir, which are also among the most commonly represted at national congresses over the past 20 years (Briones-Salas et al. 2014). Other species that stand out in terms of number of publications (Figure 6) are mostly medium and large mammals with a wide distribution in México (Hall 1981; Ceballos 2014). An increase use of camera traps facilitates the detection and identification of common species of medium and large size, and especially animals that are elusive or that occur at low population densities ( $\mathrm{O}^{\prime} \mathrm{C}$ onnell et al. 2011; Glen et al. 2013; Burton et al. 2015; Nielsen et al. 2012; Proulx et al. 2012). In Therya, the set of species detected occurs generally in inventories, leaving other ecological approaches with records from camera traps unused.

On the other hand, species of the orders Eulipotyphla, Cingulata and Pilosa are the least considered in Therya. Shrews have long been a neglected group, with limited interest by the scientific community in México due to their diminutive nature (e. g., lack of notable "charisma"), and the difficulty of observation, capture and taxonomic identification (Guevara 2019). These animals, along with armadillos (Dasypus novemcinctus) and tamandúas (Tamandua mexicana), were most frequently mentioned in faunal lists or diversity analysis, so they are not the main object of research. Even the journal Edentata, published by the Anteater, Sloth, and Armadillo Specialist Group of the International Union for Conservation of Nature (IUCN), only contains six articles on Mexican taxa between 2010 and 2019 (IUCN SSC anteater, sloth and armadillo specialist group 2020). An increase in publications will require a substantial investment to carry out continuous and long-term studies that allow obtaining unique information. The role of some species as carriers and transmitters of diseases can be taken advantage of for securing funds; for example, the armadillo as an infectious agent of human leprosy (Mycobacterium leprae; Escobar and Amezcua 1981; Truman et al. 2011).

A little-addressed order in Therya is Primates. In this case, there is a trend for authors with research in México to publish in specialized journals, between 2010-2019, 46 such publications accumulated in the American Journal of Primatology ( $n=31)$, Primates $(n=12)$, and Neotropical Primates ( $n=3$; American Society of Primatologist 2020; IUCN SSC Primates Specialist Group 2020; Japan Monkey Center 2020). Specialized journals for particular taxa may generate additional interest to publish in them.

Since its first publication in 1994, NOM-059-SEMARNAT-2010 has been a reference for the conservation status of Mexican species (SEMARNAT 2002). The species under some risk category that are represented in Therya comprise almost $50 \%$ of the species included in the NOM059-SEMARNAT-2010 (García-Aguilar et al. 2017), although just over half of these ( $S=57$ species) were mentioned only in faunal lists or in diversity analyses, thereby contributing to understanding of the range of these species, one of the four criteria considered to be included in the NOM059-SEMARNAT-2010 (Tambutti et al. 2001). However, the specific information for the rest of the criteria habitat status, biological vulnerability and impact of human activity (Tambutti et al. 2001) is very limited for all species in general.

The number of species included in NOM-059-SEMARNAT-2010 generally increased from 204 in 1994, to 236 in 2019, although the 2010 listing stood out for having 245 species listed (SEMARNAT 1994, 2010, 2015, 2019). Fully $44 \%$ of the current species at risk are mentioned in Therya, and this number is expected to increase to $51 \%$ in the next decade. This number will be lower if species additions to NOM-059-SEMARNAT-2010 decline in the future, or if species are shifted to lower risk categories. Clearly, further work is needed to justify risk categories and to design strategies to reverse conservation threats; these should be considerd as urgent needs in Mexican mammalogy.

The themes addressed in Mexican mammalogy have varied over time. For most of the $20^{\text {th }}$ century, workers emphasized distribution, taxonomy, and phylogeny, followed by parasitism, anatomy, and reproduction (GuevaraChumacero et al. 2001). These issues assumed lower stature when ecology gained strength in the field of mammalogy after the creation of various institutions focused on it (e.g., INECOL, Secretary of Urban Development and Ecology, National Institute of Ecology). We believe this likely was associated with continued transformation and degradation of habitat due to anthropogenic action, but also to general interest in recovering species and ecosystems (GuevaraChumacero et al. 2001; Sadlier et al. 2004; Barea-Azeón et al. 2007; Lira-Torres and Briones-Salas 2011; Munguía-Carrara et al. 2019). Studies of physiology and behavior have remained very uncommon in Therya and generally are underrepresented fields of study in Mexican mammalogy (Guevara-Chumacero et al. 2001; Briones-Salas et al. 2014).

Therya has published a number of papers that have expanded knowledge concerning the national mammal fauna over the last decade. Its success in attracting a greater number of publications is also reflected in the fact that an exclusive space for scientific notes Therya Notes (http://mastozoologiamexicana.com/ojs/index.php/theryanotes/) was recently established, allowing Therya journal to focus solely on scientific articles. Likewise, few mammalian orders dominate publications in Therya. We believe that Mexican mammalogists should strive to dedicate attention to the least studied groups and species. Issues such as ecology, diversity, distribution and conservation have flourished in recent years, marking a trend that capitalizes strongly on indirect study methods. The publications in Therya expanding our 
knowledge of Mexican mammals and highlights some information gaps that require attention in future research. We recommend the integration of innovative themes / topics, diverse methods, as well as the collaborations between institutions. This can maximize both the amount of information obtained, and the impact and utility that they may provide. They can also increase the impact factor of Therya and to build our understanding of Mexican mammals while simultaneously fostering understanding of their conservation and management needs.

\section{Acknowledgments}

The authors would like to thank two anonymous reviewers and the handling editor for their valuable comments that enriched the content and scope of the manuscript. This study was partially funded by the Universidad Autónoma de Querétaro, University of California - Davis, and Soluciones Ambientales Itzeni, A. C.

\section{Literature cited}

Álvarez-Castañeda, S. T., C. A. Segura-Trujlllo, and W. Z. Lidicker JR. 2019. Impact of the American Society of Mammalogists on the internationalization of mammalogy. Journal of Mammalogy 100:751-762.

Álvarez-Castañeda, S. T., C. Lorenzo, C. A. Sergura-Trujillo, and S. G. Pérez-Consuegra. 2019. Two new species of Peromyscus from Chiapas, México, and Guatemala. Pp. 543-558 in, From field to laboratory: a memorial volume in honor of Robert $\mathrm{J}$. Baker (Bradley, R. D., H. H. Genoways, D. J. Schmidly, and L. C. Bradley, eds.). Special Publications, Museum of Texas Tech University. Lubbock, U.S.A. .

American Society of Primatologists. 2020. American Journal of Primatology. https://www.asp.org/journal/. Consulted December 152020.

Arcangeli, J., J. E. Light, and F. A. Cervantes. 2018. Molecular and morphological evidence of the diversification in the gray mouse opossum, Tlacuatzin canescens (Didelphimorphia), with description of a new species. Journal of Mammalogy 99:138-158.

Arechavala-Vargas, R. 2011. Las universidades y el desarrollo de la investigación científica y tecnológica en México: una agenda de investigación. Revista de la Educación Superior 2:41-57.

Arechavala-Vargas, R., and C. F. Sánchez-Cervantes. 2017. Las universidades públicas mexicanas: los retos de las transoformaciones institucionales hacia la investigación y la transferencia de conocimiento. Revista de la Educación Superior 46:21-37.

Arizmendi, M. A., M. L. Martínez, V. León-Régagnon, G. OrtegaLeite, AND F. Álvarez. 2015. La Revista Mexicana de Biodiversidad, a 10 años de su creación. Revista Mexicana de Biodiversidad 86:843-848.

Asociación Mexicana de Mastozoología A. C. (AMMAC). 2020. Therya. https://www.revistas-conacyt.unam.mx/therya/index.php/THERYA/index. Consulted September 242020.

BAKER, R. H. 1991. The classification of Neotropical MammalsA Historical Résumé. Pp. 7-32, in Latin American Mammalogy: History, biodiversity, and education (Mares, M. A., and D. J. Schmidly, eds.). Univ. Oklahoma, Univ. Press. Norman, U.S.A.
Barea-Azeón, J. M., E. Virgós, E. Ballesteros-Duperón, M. Molé́n, AND M. Chirosa. 2007. Surveying carnivores at large spatial scales: a comparison of four broad-applied methods. Biodiversity and Conservation 16:1213-1230.

Briones-Salas, M., D. Ramos, and Y. Santiago. 2014. Análisis de los trabajos presentados en los Congresos Nacionales organizados por la Asociación Mexicana de Mastozoología (AMMAC). Therya 5:461-480.

Burton, A. C., E. Nellson, D. Moreira, A. Ladle, R. Steenweg, J. T. Fisher, E. Bayne, AND S. Boutin. 2015. Wildlife camera trapping: a review and recommendations for linking surveys to ecological processes. Journal of Applied Ecology 52:675-685.

Camargo, I., and S. T. Álvarez-Castañeda. 2020. A new species and three subspecies of the desert shrew (Notiosorex) from the Baja California peninsula and California. Journal of Mammalogy 101:872-886.

Carleton, M. D., R. D. Fisher, A. L. Gardner, L. K. Gordon, H. L. KAfKa, C. A. LudWig, AND D. F. Schmidt. 1993. Twenty-year index to Journal of Mammalogy. Volumes 51-70 inclusive, 1970-1989. The American Society of Mammalogists, Allen Press, Inc. Lawrence, U.S.A.

Ceballos, G. 2014. Mammals of México. Johns Hopkins University Press. Baltimore, U.S.A.

Cicero-Sabido, R. 2006. ¿Por qué los autores mexicanos no envían trabajos importantes a las revistas médicas mexicanas?: Un comentario breve. Gaceta médica de México 142:128-129. ColweLl, R. K. 2013. EstimateS 9.1: Statistical estimation of species richness and shared species from samples. Version 9. User's guide. http://purl.oclc.org/estimates. Consulted September 242020.

Contreras, F., G. Buzeta, L. Paredes, and L. Pedraja-Rejas. 2015. Importancia de las publicaciones académicas: algunos problemas y recomendaciones a tener en cuenta. Idesia (Arica) 33:111-119.

Dahlgren, D. K., R. D. Elmore, D. A. Smith, A. Hurt, E. B. Arnett, AND J. W. ConnelLy. 2012. Use of dogs in wildlife research and management. Pp. 140-153, in Wildlife Techniques Manual (Silvy, N., ed.). Vol. 1. The Wildlife Society Inc. Washington, D.C., U.S.A.

Diario Oficial de la Federación (DOF). 2019. Presupuesto de Egresos de la Federación para el Ejercicio Fiscal 2020. México. 11 de diciembre de 2019.

Díaz-Pulido, A., and E. Payán Garrido. 2012. Manual de fototrampeo: una herramienta de investigación para la conservación de la biodiversidad en Colombia. Instituto de Investigaciones de Recursos Biológicos Alexander von Humboldt y Panthera Colombia. Bogotá, D.C., Colombia.

Escobar, A., AND M. E. Amezcua. 1981. El armadillo: un nuevo animal de experimentación para el estudio de las zoonosis. Ciencia Veterinaria 3:200-212.

Escobedo-Cabrera, E. and C. Lorenzo. 2011. Nuevos registros de Sylvilagus floridanus en la Península de Yucatán, México. Therya 2:279-283.

Gallo-Reynoso, J. P. and C. Leo Ortiz. 2010. Feral cats steal milk from northern Elephant Seals. Therya 1:207-212.

García-Aguilar, M. C., J. Luévano-Esparza, and H. De la Cueva. 2017. La fauna nativa de México en riesgo y la NOM-059: ¿Están todos los que son y son todos los que están? Acta Zoológica Mexicana 33:188-198. 
García-Angélica, E., R. Tinoco-Ojanguren, and E. Tuñón-Pablos. 2012. Género y Ciencias en México. Ciencia, Revista de la Academia Mexicana de Ciencias 63:8-15.

García-Grajales, J., ANd A. Buenrostro-Silva. 2019. Las cámaras trampa y su avance tecnológico en favor de la conservación. Ciencia y Mar 22:43-51.

Gatica-Colima, A., A. Fernández-López, J. M. Martínez-Calderas. 2011. Nuevo registro de distribución de la ardilla antílope de Texas Ammospermophilus interpres para el estado de Chihuahua, México. Therya 2:289-293.

Glen, A. S., S. Cockburn, M. Nichols, J. Ekanayake, and B. WarBURTon. 2013. Optimising Camera Traps for Monitoring Small Mammals. Plos One 8:e67940.

Guevara, L. 2019. Las musarañas son importantes. Therya 10:1-2. Guevara, L., V. Sánchez-Cordero, L. León-Paniagua, And N. WoodMAN. 2014. A new species of small-eared shrew (Mammalia, Eulipotyphla, Cryptotis) from the Lacandona rain forest, México. Journal of Mammalogy 95:739-753.

Guevara-Chumacero, L. M., R. López-Wilchis, and V. Sánchéz-CorDERO. 2001. 105 años de investigación mastozoológica en México (1890-1995): Una revisión de sus enfoques y tendencias. Acta Zoológica Mexicana 83:35-72.

Guzmán-Lenis, A., and Á. Camargo-Sanabria. 2004. Importancia de los rastros para la caracterización del uso de hábitat de mamíferos medianos y grandes en el bosque de Los Mangos (Puerto López, Meta, Colombia). Acta Biológica Colombiana 9:11-22.

HaLl, E. R. 1981. The mammals of North America. Vol II. John Wiley \& Sons Inc. New York, U.S.A.

Harper, L. R., L. Lawson Handley, A. I. Carpenter, M. Ghazali, C. Di Muri, C. J. Macgregor, T. W. Logan, A. LaW, T. Breithaupt, D. S. Read, A. D. McDevitt, And D. Hänfling. 2019. Environmental DNA (eDNA) metabarcoding of pond water as a tool to survey conservation and management priority mammals. Biological Conservation 238:1-11.

Hernández-Flores, S. D., G. Vargas-Licona and G. Sánchez-Rojas. 2013. First records of the Ocelot (Leopardus pardalis) in the state of Hidalgo, México. Therya 4:99-102.

Hoffmann, A., J. Decher, F. Rovero, J. Schaer, C. Voigt, and G. WibBelt. 2010. Field methods and techniques for monitoring mammals. Pp. 482-529, in Manual on field recording techniques and protocols for All Taxa Biodiversity Inventories and Monitoring (Eymann, J., J. Degreef, C. Häuser, J. C. Monje, Y. Samyn, and D. VandenSpiegel, eds.). ABC Taxa, Publisher. Brussels, Belgium.

Institute of Biology. 2020. Revista Mexicana de Biodiversidad. Universidad Nacional Autónoma de México. http://www.revista.ib.unam.mx/index.php/bio. Consulted September 242020. Institute of Ecology. 2020. Revista Mexicana de Mastozoología (Nueva Época). Universidad Nacional Autónoma de México. http://www.revmexmastozoologia.unam.mx/ojs/index.php/ rmm/index. Consulted September 242020.

Instituto de Ecología A. C. (INECOL A. C.). 2020. Acta Zoológica Mexicana (Nueva Serie). Consejo Nacional de Ciencia y Tecnología. http://azm.ojs.inecol.mx/index.php/azm. Consulted September 242020.

international Union for Conservation of Nature Species Survival Commission (IUCN SSC) Anteater, Sloth and Armadillo SpecialIST Group. 2020. Edentata. https://www.xenarthrans.org/es/ revista-edentata/. Consulted September 242020.
International Union for Conservation of Nature Species Survival Commission (IUCN SSC) Primates Specialist Group. 2020. Neotropical Primates. http://www.primate-sg.org/neotropical primates. Consulted December 152020.

Japan Monkey Center. 2020. Primates. https://www.springer. com/journal/10329. Consulted December 152020.

Jiménez-Maldonado, R. E. And C. A. López-González. 2011. La tuza real (Agouti paca), nueva especie para la mastofauna del estado de Querétaro, México. Therya 2:285-288.

Leempoel, K., T. Hebert, and E. A. Hadly. 2020. A comparison of eDNA to camera trapping for assessment of terrestrial mammal diversity. Proceedings Royal Society B 287:1-10.

León-Tapia, M. A., J. A. Fernández, Y. Rıco, F. A. Cervantes and, A. EsPinosa de los Monteros. 2020. A new mouse of the Peromyscus maniculatus species complex (Cricetidae) from the highlands of central México. Journal of Mammalogy 101:1117-1132.

LiRA-TorRes, I., AND M. Briones-Salas. 2011. Impacto de la ganadería extensiva y cacería de subsistencia sobre la abundancia relativa de mamíferos en la Selva Zoque, Oaxaca, México. Therya 2:217-244.

Lira-Torres, I., G. Sánchez-Rojas, D. OJeda-Ramírez, ANd F. R. Gómez de AndA. 2014. Registro Notable del Puercoespín Arborícola Sphiggurus mexicanus (Rodendia: Erethizontidae) en la Sierra Madre Oriental, México. Therya 5:271-275.

Lorenzo, C., S. T. Álvarez-Castañeda, E. Arellano, J. ArroyoCabrales, J. Bolaños, M. Briones-Salas, F. A. Cervantes, J. Chablé-Santos, L. Corral, M. Cortés, P. Cortés-Calva, M. de la Paz-Cuevas, C. Elizalde-Arellano, E. Escobedo-Cabrera, E. Espinoza, E. Estrella, J. P. Gallo-Reynoso, D. F. García-Mendoza, H. A. Garza-Torres, A. González Christen, F. X. González-Cózatl, R. M. González-Monroy, N. González-Ruíz, D. Guzmán, N. F. Guzmán, S. F. Hernández-Betancourt, Y. Hortelano-Moncada, L. I. IÑiguez, A. Jiménez-Guzmán, Y. N. Kantum, L. León-Paniagua, C. López-González, J. H. López-Soto, J. C. López-Vidal, N. Martin, J. Martínez-Vázquez, S. M. A. Mejenes-López, B. Morales-Vela, R. Muñiz-Martínez, J. A. Niño-Ramírez, A. Núñez-Garduño, C. Pozo, J. Ramírez-Pulido, O. G. Retana, I. Ruan, C. I. Selem, J. Vargas, And M. A. ZúñIga-Ramos. 2012. Los Mamíferos de México en las colecciones científicas de Norteamérica. Therya 3:239-262.

Lorenzo, C., C. Lorenzo-Monterrubio, and S. F. Hernández-BetanCouRT. 2013. Las mujeres en la mastozoología mexicana. Sociedad y Ambiente 1:158-169.

Lorenzo, C., L. Guevara, and S. Hernández-Betancourt. 2014. La AMMAC a través de sus congresos. Pp. 271-290, in 30 años de la mastozoología en México (Lorenzo-Monterrubio, C., and S. Hernández Betancourt, eds.). ECOSUR-UADY-AMMAC. Ciudad de México, México.

Lyra-Jorge, M. C., G. Ciocheti, V. R. Pivello, and S. T. Meirelles. 2008. Comparing methods for sampling large- and médiumsized mammals: camera traps and track plots. European Journal of Wildlife Research 54:739-744.

Mammal Diversity Database. 2020. American Society of Mammalogists. http://www.mammaldiversity.org. Consulted September 242020.

Mandujano, S. 2019. Analysis and trends of photo-trapping in México: text mining in R. Therya 10:25-32.

Martínez-Coronel, M., R. Bautista, and M. I. Verona-Trejo. 2013. Albinismo platinado en Liomys pictus (Mammalia: Heteromyidae). Therya 4:641-645. 
Meek, P. D., G. A. Ballard, J. Sparkess, M. Robinson, B. Nesbitt, AND P. J. S. Fleming. 2019. Camera trap theft and vandalism: occurrence, cost, prevention and implications for wildlife research and management. Remote Sensing in Ecology and Conservation 5:160-168.

Mendoza-Rojas, J. 2019. Presupuesto federal de educación superior en el primer año de gobierno de Andrés Manuel López Obrador: Negociaciones y retos. Revista de Educación Superior 48:51-82.

Munguía-Carrara, M., J. Equihua Benítez, M. Schmidt, and M. Equinua-Zamora. 2019.. Diversidad funcional en los mamíferos de México e integridad ecosistémica. Pp. 388402, in Antropización: Primer análisis integral (Ornelas García, C. P., F. Álvarez, and A. Wieger, eds.). Color Arte. Ciudad de México, México.

Nielsen, E., D. Christianson, J. Gaillard, D. Halley, J. Linell, M. Odden, M. Panzacchi, C. Toïgo, and B. Zimmermann. 2012. Describing food habits and predation: field methods and statistical considerations. Pp. 256-272, in Carnivore Ecology and Conservation, A handbook of techniques (Boitani, L., and R. Powell, eds.). Oxford University Press. New York, U.S.A.

O'Connell, A. F., J. D. Nichols, and K. U. Karanth. 2011. Camera traps in animal ecology: methods and analyses. Springer Science and Business Media. Tokyo, Japan.

Powell, R. A., And G. Proulx. 2003. Trapping and marking terrestrial mammals for research: integrating ethics, performance criteria, techniques, and common sense. Ilar Journal 44:259-276.

Proulx, G., M. R. Cattet, And R. A. Powell. 2012. Humane and efficient capture and handling methods for carnivores. Pp. 70-129, in Carnivore ecology and conservation: A handbook of techniques (Boitani L., and R. Powell, eds.). Oxford University Press Inc., New York. New York, U.S.A.

Putman, R. 1984. Facts from faeces. Mammal Review 14:79-97.

Ramírez-Pulido, J., and A. Castro-Campillo. 1993. Diversidad mastozoológica en México. Revista de la Sociedad Mexicana de Historia Natural 44:413-427.

Ramírez-Pulido, J., N. González-Ruíz, A. L. Gardner, and J. ArRoyo-Cabrales. 2014. List of recent land mammals from México, 2014. Special Publications, Museum of Texas Tech University 63:1-69.

Ramírez-Pulido, J., N. González-Ruíz, and D. F. García-Mendoza. 2017. Reference on Mexican mammals: Origin and impact. Therya 8:151-170.

Ruiz-Argüelles, G. J. 1999. Reflexiones sobre los rechazos de artículos en la Revista de Investigación Clínica. Revista de Investigación Clínica 51:95-96.

Sadlier, L. M. J., C. C. Webbon, P. J. Backer, and S. Harris. 2004. Methods of monitoring red foxes Vulpes vulpes and badgers $\mathrm{Me}$ les meles: are field signs the answer? Mammal Review 34:75-98.

Salerno, P. E., M. Páez-Vacas, J. M. Guayasamin, and J. L. Stynoski. 2020. Male principal investigators (almost) don't publish with women in ecology and zoology. Plos One 15:e0233803.

Sánchez-Cordero, V., And R. Medellín. 2011. Dr. Bernardo Villa Ramírez. Therya 2:197-198.

Sánchez-Cordero, V., F. Botello, J. J. Flores-Martínez, R. A. Gómez-Rodríguez, L. Guevara, G. Gutiérrez-Granados, and A. RodríGuez-Moreno. 2014. Biodiversidad de Chordata (Mammalia) en México. Revista Mexicana de Biodiversidad 85:496-504.
Schroeder, N. M., A. Panebianco, R. González-Musso, and P. CarMANCHAH. 2020. An experimental approach to evaluate the potential of drones in terrestrial mammal research: a gregarious ungulate as a study model. The Royal Society 7:1-9.

Secretaría de Medio Ambiente y Recursos Naturales (SEMARNAT). 1994. Norma Oficial Mexicana NOM-059-ECOL-1994, que determina las especies y subespecies de flora y fauna silvestres terrestres y acuáticas en peligro de extinción, amenazadas, raras y las sujetas a protección especial, y que establece especificaciones para su protección. Diario Oficial de la Federación, May 161994.

Secretaría del Medio Ambiente y Recursos Naturales (SemarNAT). 2002. Norma Oficial Mexicana NOM-059-ECOL-2001, protección ambiental-especies nativas de México de flora y fauna silvestres-categorías de riesgo y especificaciones para su inclusión, exclusión o cambio-Lista de especies en riesgo. Diario Oficial de la Federación, March 062002.

Secretaría de Medio Ambiente y Recursos Naturales (SEMARNAT). 2010. Norma Oficial Mexicana NOM-059-SEMARNAT-2010, protección ambiental-species nativas de México de flora y fauna silvestres-categorías de riesgo y especificaciones para su inclusión, exclusión o cambio-Lista de especies en riesgo. Diario Oficial de la Federación, December 302010.

Secretaría del Medio Ambiente y Recursos Naturales (SemarNAT). 2012. Informe de la situación del medio ambiente en México. Compendio de Estadísticas Ambientales Indicadores Clave y de Desempeño Ambiental. Secretaría del Medio Ambiente y Recursos Naturales. Edición 2012. Ciudad de México, México. https://apps1.semarnat.gob.mx:8443/dgeia/ informe 12eng/pdf/Informe 2012.pdf. Consulted December 152020.

Secretaría de Medio Ambiente y Recursos Naturales (SemarNAT). 2015. Modificación del Anexo Normativo III, Lista de especies en riesgo de la Norma Oficial Mexicana NOM059-SEMARNAT-2010, protección ambiental-especies nativas de México de flora y fauna silvestres-categorías de riesgo y especificaciones para su inclusión, exclusión o cambio-Lista de especies en riesgo. Diario Oficial de la Federación, December 212015.

Secretaría de Medio Ambiente y Recursos Naturales (SEMARNAT). 2019. Modificación del Anexo Normativo III, Lista de especies en riesgo de la Norma Oficial Mexicana NOM059-SEMARNAT-2010, protección ambiental-especies nativas de México de flora y fauna silvestres-categorías de riesgo y especificaciones para su inclusión, exclusión o cambio-Lista de especies en riesgo. Diario Oficial de la Federación, November 142019.

Sosa-Escalante, J. E., M. C. MacSwiney, and J. M. Pech-Canché. 2014. Visión pasada, presente y futura de la AMMAC. Pp. 217-231 in 30 años de la mastozoología en México (LorenzoMonterrubio, C., and S. Hernández Betancourt, eds.). ECOSUR-UADY-AMMAC. Ciudad de México, México.

Tambuttı, M., A. Aldama, O. Sánchez, R. Medellín, and J. Soberón. 2001. La determinación del riesgo de extinción de especies silvestres en México. Gaceta Ecológica 60:11-21.

Tomas, W. M., AND G. H. B. Miranda. 2003. Uso de armadilhas fotográficas em levantamentos populacionais. Pp. 243-268, in Métodos de estudo em biologia da conservação e manejo da vida silvestre (Cullen, Jr. L., R. Rudran, and C. Valladares Pádua, eds.). Universidade Federal do Paraná. Curitiba, Brasil. 
Truman, R. W., P. Singh, R. Sharma, P. Busso, J. Rougemont, A. Paniz-Mondolfi, A. Kapopoulou, S. Brisse, D. M. Scollard, T. P. Gillis, AND S. T. Cole. 2011. Probable zoonotic leprosy in the Southern United States. The New England Journal of Medicine 364:1626-1633.

Valencia-Herverth, R. and J. Valencia-Herverth. 2012. Presencia del Gato Montés (Lynx rufus) en selvas tropicales del estado de Hidalgo, México. Therya 3:81-85.

Verona-Trejo, M. I., R. Bautista and M. Martínez-Coronel. 2012. Registro de la zorra norteña (Vulpes macrotis) para el sur de Sonora. Therya 3:101-104.

Viloria-Gómora, L., And L. Medrano-González. 2015. Population ecological traits of Tursiops truncatus putative morphotypes in the transitional region of the Mexican Pacific Ocean. Therya 6:351-370.

Webster, S. C., And J. C. Beasley. 2019. Influence of Lure Choice and Survey Duration on Scent Stations for Carnivore Surveys. Wildlife Society Bulletin 43:661-668.

ZÁRATE, A. 1999. El doble estándar (anfipatía) que caracteriza a algunos científicos mexicanos en su actuación como revisores de manuscritos y proyectos de investigación. Ciencia 30:35-36.

Associated editor: Consuelo Lorenzo

Submitted: October 30, 2020; Reviewed: November 25, 2020;

Accepted: January 13, 2020; Published on line: January 19, 2021. 


\section{Appendix 1}

Number and type of publications by order, family and species in Therya. Included conservaton status (NOM059-SEMARNAT-2010): Endemic species of México $(*)$, threatened (A), Special Protection (Pr), Endangered (P). Publications (Pb), Articles (At), notes (Nt), diversity studies (Div); SEMARNAT-NOM-059-2010 (NOM).

\begin{tabular}{|c|c|c|c|c|c|c|c|}
\hline Order & Species & $\mathrm{Pb}$ & At & Nt & Div & NOM & $\begin{array}{l}\text { Artibeus jamaicensis } \\
\text { Artibeus lituratus }\end{array}$ \\
\hline \multicolumn{7}{|c|}{ Didelphimorphia } & Artibeus phaeotis \\
\hline & Didelphidae & & & & & & Artibeus toltecus \\
\hline & Caluromys derbianus & 2 & & & 2 & $A$ & Carollia perspicillata \\
\hline & Chironectes minimus & 1 & 1 & & & $\mathrm{P}$ & Carollia sowelli \\
\hline & Didelphis marsupialis & 9 & 1 & & 8 & & Carollia subrufa \\
\hline & Didelphis virginiana & 16 & 1 & 1 & 14 & & Centurio senex \\
\hline & Marmosa mexicana & 4 & & & 4 & & Chiroderma salvini \\
\hline & Philander opossum & 4 & & & 4 & & Chiroderma villosum \\
\hline & Tlacuatzin canecens & 4 & & 1 & 3 & & Choeroniscus godmani \\
\hline \multicolumn{7}{|l|}{ Cingulata } & Choeronycteris mexicana \\
\hline & Dasypodidae & & & & & & Chrotopterus auritus \\
\hline & Dasypus novemcinctus & 15 & & & 15 & & Dermanura azteca \\
\hline \multirow[t]{5}{*}{ Pilosa } & & & & & & & Dermanura phaeotis \\
\hline & Cyclopedidae & & & & & & Dermanura tolteca \\
\hline & Cyclopes didactylus & 1 & & & 1 & $P$ & Dermanura watsoni \\
\hline & Myrmecophagidae & & & & & & Desmodus rotundus \\
\hline & Tamandua mexicana & 6 & & 1 & 5 & $P$ & Diaemus youngi \\
\hline \multirow[t]{3}{*}{ Sirenia } & & & & & & & Diphylla ecaudata \\
\hline & Trichechidae & & & & & & Enchisthenes hartii \\
\hline & Trichechus manatus manatus & 4 & 2 & 1 & 1 & $\mathrm{P}$ & Gliphonycteris sylvestris \\
\hline \multirow{45}{*}{ Eulipotyphl } & & & & & & & Glossophaga commissarisi \\
\hline & Soricidae & & & & & & Glossophaga leachii \\
\hline & ${ }^{*}$ Cryptotis alticola & 2 & & & 2 & $\operatorname{Pr}$ & Glossophaga morenoi \\
\hline & *Cryptotis goldmani & 2 & & & 2 & $\operatorname{Pr}$ & Glossophaga soricina \\
\hline & Cryptotis goodwini & 3 & & & 3 & & Glyphonycteris sylvestris \\
\hline & Cryptotis griseoventris & 3 & & 1 & 2 & & Hylonycteris underwoodi \\
\hline & Cryptotis lacandonensis & 2 & & & 2 & & Lampronycteris brachyotis \\
\hline & ${ }^{*}$ Cryptotis magnus & 1 & & & 1 & $\operatorname{Pr}$ & Leptonycteris nivalis \\
\hline & Cryptotis mayensis & 1 & & & 1 & $\operatorname{Pr}$ & Leptonycteris yerbabuenae \\
\hline & Cryptotis merriami & 2 & & & 2 & & Lonchorhina aurita \\
\hline & Cryptotis mexicana & 5 & & 1 & 4 & & Lophostoma brasiliense \\
\hline & ${ }^{*}$ Cryptotis nelsoni & 1 & & & 1 & $\operatorname{Pr}$ & Lophostoma evotis \\
\hline & ${ }^{*}$ Cryptotis obscurus & 2 & & & 2 & $\operatorname{Pr}$ & Macrotus californicus \\
\hline & ${ }^{*}$ Cryptotis parvus & 6 & & & 6 & $\operatorname{Pr}$ & Macrotus waterhousii \\
\hline & ${ }^{*}$ Cryptotis peregrina & 2 & & & 2 & $\operatorname{Pr}$ & Micronycteris microtis \\
\hline & Cryptotis phillipsii & 1 & & & 1 & & Mimon cozumelae \\
\hline & Cryptotis pueblensis & 1 & & & 1 & & Mimon crenulatum \\
\hline & Cryptotis tropicalis & 2 & & & 2 & $\operatorname{Pr}$ & ${ }^{*}$ Musonycteris harrisoni \\
\hline & ${ }^{*}$ Megasorex gigas & 2 & & & 2 & A & Phyllostomus discolor \\
\hline & Notiosorex cockrumi & 1 & & & 1 & & Platyrrhinus helleri \\
\hline & Notiosorex crawfordi & 2 & & & 2 & $A$ & Sturnira hondurensis \\
\hline & ${ }^{*}$ Notiosorex evotis & 2 & & & 2 & A & Sturnira lilium \\
\hline & *Notiosorex villai & 1 & & & 1 & A & Sturnira ludovici \\
\hline & Sorex arizonae & 1 & & & 1 & $P$ & Sturnira parvidens \\
\hline & Sorex chiapensis & 1 & & & 1 & & Trachops cirrhosus \\
\hline & Sorex cristobalensis & 1 & & & 1 & & Uroderma bilobatum \\
\hline & Sorex emarginatus & 3 & & & 3 & & Uroderma magnirostrum \\
\hline & Sorexixtlanensis & 2 & & & 2 & & Vampyressa thyone \\
\hline & *Sorex macrodon & 1 & & & 1 & $A$ & Vampyrodes caraccioli \\
\hline & Sorex mediopua & 2 & & & 2 & & Vampyrum spectrum \\
\hline & *Sorex milleri & 1 & & & 1 & A & Mormoopidae \\
\hline & Sorex monticola & 2 & & & 2 & A & Mormoops megalophylla \\
\hline & Sorex oreopolus & 5 & 1 & & 4 & & Pteronotus davyi \\
\hline & Sorex orizabae & 1 & & & 1 & & Pteronotus parnellii \\
\hline & Sorex ornatus & 1 & & & 1 & & Pteronotus personatus \\
\hline & Sorex salvini & 2 & & & 2 & & Noctilionidae \\
\hline & Sorex saussurei & 5 & & & 5 & & Noctilio leporinus \\
\hline & *Sorex sclateri & 2 & & & 2 & A & Vespertilionidae \\
\hline & *Sorex stizodon & 2 & & & 2 & A & Eptesicus fuscus \\
\hline & Sorex ventralis & 2 & & & 2 & & Antrozous pallidus \\
\hline & *Sorex salvini veraecrucis & 2 & & & 2 & $\operatorname{Pr}$ & Baeodon alleni \\
\hline & Sorex veraepacis & 1 & & & 1 & & Bauerus dubiaquercus \\
\hline & Talpidae & & & & & & Corynorhinus mexicanus \\
\hline & Scalopus aquaticus & 1 & & & 1 & $P$ & Corynorhinus townsendii \\
\hline & Scapanus latimanus & 2 & & & 2 & A & Eptesicus brasilensis \\
\hline \multirow{5}{*}{ Chiroptera } & & & & & & & Eptesicus furinalis \\
\hline & Emballonuridae & & & & & & Eptesicus fuscus \\
\hline & Balantiopteryx io & 2 & & & 2 & & Euderma maculatum \\
\hline & Balantiopteryx plicata & 8 & & & 8 & & Idionycteris phyllotis \\
\hline & Centronycteris centralis & 3 & & & 3 & $\operatorname{Pr}$ & Lasiurus blossevillii \\
\hline
\end{tabular}

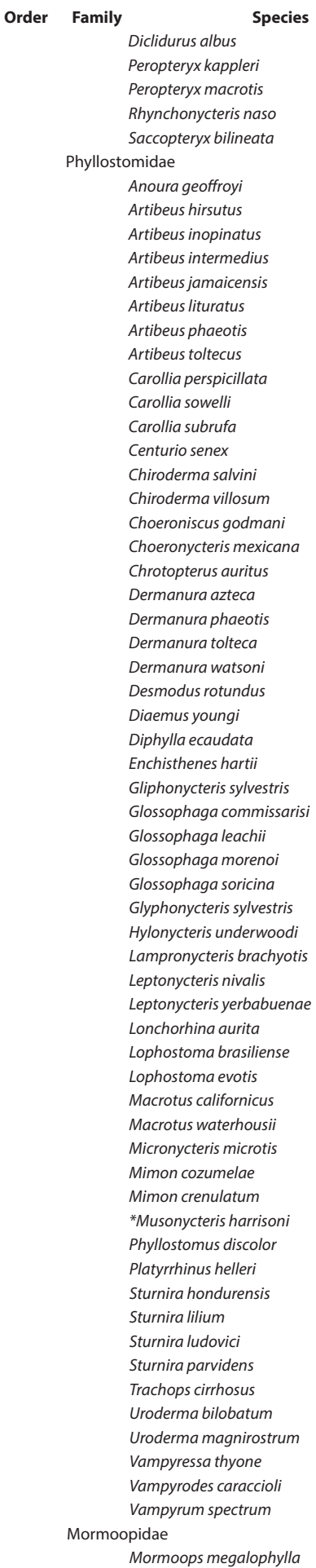


Lasiurus borealis

Lasiurus cinereus

Lasiurus ega

Lasiurus intermedius

Lasiurus xanthinus

Myotis californicus

Myotis ciliolabrun

Myotis elegans

Myotis fortidens

Myotis keaysi

Myotis melanorhinus

Myotis nigricans

Myotis occultus

Myotis thysanodes

Myotis velifer

Myotis volans

Myotis yumanensis

Nycticeius humeralis

Parastrellus hesperus

Perimiotys subflavus

Rhogeessa aeneus

Rhogeessa alleni

Rhogeessa gracilis

Rhogeessa parvula

Rhogeessa tumida

Molossidae

*Cynomops mexicanus

Eumops auripendulus

Eumops bonariensis

Eumops glaucinus

Eumops perotis

Eumops underwoodi

Molossus aztecus

Molossus molossus

Molossus rufus

Molossus sinaloae

Nyctinomops aurispinosa

Nyctinomops femorosaccus

Nyctinomops laticaudatus

Nyctinomops macrotis

Promops centralis

Natalidae

Tadarida brasiliensis

Natalus lanatus

Natalus mexicanus

Natalus stramineus

Cetartiodactyla

Ziphiidae

Mesoplodon peruvianus

Ziphius cavirostris

Delphinidae

Delphinus capensis

Delphinus delphis

Grampus griseus

Lagenodelphis hosei

Orcinus orca

Pseudorca crassidens

Stenella attenuata

Stenella coeruleoalba

Stenella longirostris

Steno bredanensis

Physeteridae

Kogia breviceps

Kogia sima

Eschrichtidae

Eschrichtius robustus

Balaenopteridae

Balaenoptera edeni

Megaptera novaeangliae

Antilocapridae

Antilocapra americana

Bovidae

Bos indicus

Bos taurus

Ovis canadensis cremnobates

Cervidae

Mazama pandora

Mazama temama

Odocoileus hemionus

Odocoileus virginianus
Div

NOM

7

5

3

2

3

6
1

4

Baiomys musculus

Baiomys taylori

*Habromys simulatus

Handleyomys alfaroi

Handleyomys rostratus

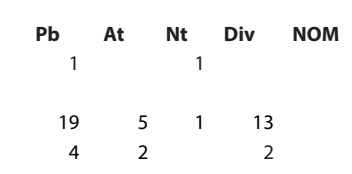

$11 \quad 10$

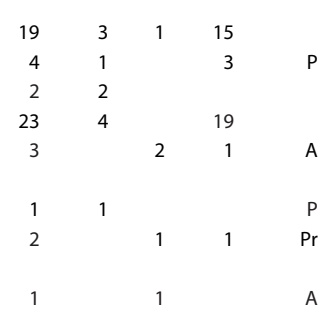

$\begin{array}{rrrrr}7 & 3 & 3 & 1 & \mathrm{P} \\ & & & & \\ 9 & & 1 & 8 & \mathrm{P} \\ 2 & & 1 & 1 & \mathrm{~A} \\ 1 & 1 & & & \\ 20 & 13 & & 7 & \mathrm{~A} \\ 8 & & & 8 & \\ 5 & & & 5 & \mathrm{~A} \\ & & & & \\ 11 & & & 11 & \\ 19 & 2 & 1 & 16 & \\ 6 & & & 6 & \mathrm{Pr} \\ 17 & & & 17 & \end{array}$

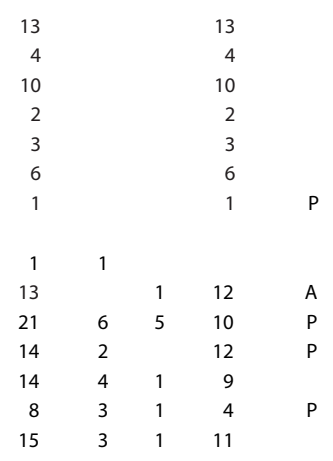




\begin{tabular}{|c|c|c|c|c|c|c|c|c|c|c|c|c|c|c|c|}
\hline Order & Family & Species & $\mathbf{P b}$ & At & Nt & Div & NOM & Order & Family & Species & $\mathrm{Pb}$ & At & Nt & Div & NOM \\
\hline & & Hodomys alleni & 2 & & & 2 & & & & Chaetodipus nelsoni & 3 & & & 3 & \\
\hline & & Microtus mexicanus & 5 & & & 5 & & & & Chaetodipus penicillatus & 1 & & & 1 & \\
\hline & & Microtus quasiater & 1 & & & 1 & & & & ${ }^{*}$ Chaetodipus siccus & 1 & 1 & 1 & & A \\
\hline & & ${ }^{*}$ Nelsonia goldmani & 4 & 1 & 1 & 2 & $\operatorname{Pr}$ & & & Dipodomys merriami & 3 & & & 3 & \\
\hline & & ${ }^{*}$ Nelsonia neotomodon & 1 & 1 & & & $\operatorname{Pr}$ & & & Dipodomys nelsoni & 1 & & & 1 & \\
\hline & & Neotoma leucodon & 4 & 1 & & 3 & & & & Dipodomys ordii & 6 & & & 6 & \\
\hline & & Neotoma mexicana & 5 & & & 5 & & & & Dipodomys ornatus & 2 & 1 & 1 & 1 & \\
\hline & & Neotoma micropus & 1 & & & 1 & & & & *Dipodomys philliipsii & 4 & 1 & 1 & 3 & $\operatorname{Pr}$ \\
\hline & & Neotoma nelsoni & 1 & & & 1 & & & & Heteromys desmarestianus & 3 & 1 & 1 & 2 & \\
\hline & & Neotoma palatina & 2 & & & 2 & & & & Heteromys gaumer & 3 & & & 3 & \\
\hline & & Neotomodon alstoni & 2 & & & 2 & & & & Heteromys irroratus & 2 & & & 2 & \\
\hline & & Nyctomys sumichrasti & 2 & & & 2 & & & & Heteromys salvini & 1 & & & 1 & \\
\hline & & Oligoryzomys fulvescens & 5 & & & 5 & & & & *Heteromys spectabilis & 1 & & & 1 & $\operatorname{Pr}$ \\
\hline & & Onychomys arenicola & 1 & & & 1 & & & & Liomys irroratus & 4 & & & 4 & \\
\hline & & Onychomys leucogaster & 1 & & & 1 & & & & Liomys pictus & 4 & & 1 & 3 & \\
\hline & & Onychomys torridus & 1 & & & 1 & & & & Perognathus flavescens & 1 & & & 1 & \\
\hline & & Oryzomys albiventer & 2 & & & 2 & & & & Perognathus flavus & 4 & & & 4 & \\
\hline & & Oryzomys alfaroi & 1 & & & 1 & & & & Perognathus merriami & 1 & & & 1 & \\
\hline & & Oryzomys chapmani & 1 & & & 1 & & Lagomorph & & & & & & & \\
\hline & & Oryzomys couesi & 5 & 1 & & 4 & & & Leporida & & & & & & \\
\hline & & Oryzomys melanotis & 1 & & & 1 & & & & Lepus californicus & 7 & 2 & 2 & 5 & \\
\hline & & Oryzomys mexicanus & 1 & & & 1 & & & & *Lepus californicus insularis & 2 & 2 & 2 & & $\operatorname{Pr}$ \\
\hline & & Oryzomys rostratus & 1 & & & 1 & & & & Lepus callotis & 4 & 4 & 4 & & \\
\hline & & Osgoodomys banderanus & 1 & & & 1 & & & & *Lepus flavigularis & 6 & 6 & 5 & & $P$ \\
\hline & & Otonyctomys hatti & 1 & & & 1 & A & & & ${ }^{*}$ Romerolagus diazi & 2 & 1 & I & 1 & $\mathrm{P}$ \\
\hline & & Ototylomys phyllotis & 2 & & & 2 & & & & Sylvilagus audubonii & 6 & 6 & 5 & & \\
\hline & & Peromyscus aztecus & 6 & & & 6 & & & & Sylvilagus brasiliensis & 1 & 1 & 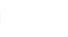 & & \\
\hline & & Peromyscus beatae & 1 & & & 1 & & & & *Sylvilagus cunicularis & 7 & 1 & 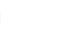 & 6 & \\
\hline & & Peromyscus boylii & 2 & & & 2 & & & & Sylvilagus floridanus & 12 & & 1 & 11 & \\
\hline & & Peromyscus difficilis & 6 & 1 & 1 & 4 & & & & *Sylvilagus insonus & 1 & 1 & 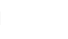 & & $\mathrm{P}$ \\
\hline & & Peromyscus eremicus & 2 & & & 2 & & Primates & & & & & & & \\
\hline & & Peromyscus furvus & 1 & & & 1 & & & Atelidae & & & & & & \\
\hline & & Peromyscus gratus & 5 & & & 5 & & & & Alouatta palliata mexicana & 3 & 1 & 2 & & $\mathrm{P}$ \\
\hline & & Peromyscus gymnotis & 1 & & & 1 & & & & Alouatta villosa & 3 & 1 & 1 & 1 & $\mathrm{P}$ \\
\hline & & Peromyscus hylocetes & 2 & & & 2 & & & & Ateles geoffroyi & 6 & 2 & 2 & 4 & $\mathrm{P}$ \\
\hline & & Peromyscus leucopus & 6 & 1 & & 5 & & & & & & & & & \\
\hline & & Peromyscus levipes & 6 & & & 6 & & & & & & & & & \\
\hline & & Peromyscus maniculatus & 4 & & & 4 & & & & & & & & & \\
\hline & & Peromyscus megalops & 1 & & & 1 & & & & & & & & & \\
\hline & & Peromyscus melanophrys & 6 & & & 6 & & & & & & & & & \\
\hline & & Peromyscus melanotis & 5 & 1 & & 4 & & & & & & & & & \\
\hline & & Peromyscus mexicanus & 6 & & & 6 & & & & & & & & & \\
\hline & & Peromyscus pectoralis & 3 & & & 3 & & & & & & & & & \\
\hline & & Peromyscus perfulvus & 1 & & & 1 & & & & & & & & & \\
\hline & & Peromyscus spicilegus & 1 & & & 1 & & & & & & & & & \\
\hline & & Peromyscus yucatanicus & 2 & & & 2 & & & & & & & & & \\
\hline & & *Peromyscus zarhynchus & 2 & & & 2 & & & & & & & & & \\
\hline & & Reithrodontomys chrysopsis & 1 & & & 1 & & & & & & & & & \\
\hline & & Reithrodontomys fulvescens & 8 & & & 8 & & & & & & & & & \\
\hline & & Reithrodontomys gracilis & 5 & 1 & & 4 & & & & & & & & & \\
\hline & & Reithrodontomys hirsutus & 1 & & & 1 & & & & & & & & & \\
\hline & & Reithrodontomys megalotis & 4 & & & 4 & & & & & & & & & \\
\hline & & Reithrodontomys mexicanus & 4 & & & 4 & & & & & & & & & \\
\hline & & Reithrodontomys microdon & 1 & & & 1 & A & & & & & & & & \\
\hline & & ${ }^{*}$ Reithrodontomys spectabilis & 1 & & & 1 & A & & & & & & & & \\
\hline & & Reithrodontomys sumichrasti & 5 & & & 5 & & & & & & & & & \\
\hline & & Reithrodontomys zacatecae & 1 & & & 1 & & & & & & & & & \\
\hline & & Sigmodon alleni & 1 & & & 1 & & & & & & & & & \\
\hline & & Sigmodon fulviventer & 2 & & & 2 & & & & & & & & & \\
\hline & & Sigmodon hispidus & 11 & & & 11 & & & & & & & & & \\
\hline & & Sigmodon leucotis & 3 & & & 3 & & & & & & & & & \\
\hline & & Sigmodon mascotensis & 1 & & & 1 & & & & & & & & & \\
\hline & & Sigmodon toltecus & 1 & & & 1 & & & & & & & & & \\
\hline & & Tylomys nudicaudus & 2 & & & 2 & & & & & & & & & \\
\hline & Muridae & & & & & & & & & & & & & & \\
\hline & & Mus musculus & 7 & 2 & 1 & 4 & & & & & & & & & \\
\hline & & Rattus rattus & 3 & & & 3 & & & & & & & & & \\
\hline & Geomyd & & & & & & & & & & & & & & \\
\hline & & ${ }^{*}$ Cratogeomys fumosus & 4 & 1 & & 3 & A & & & & & & & & \\
\hline & & Cratogeomys merriami & 1 & & & 1 & & & & & & & & & \\
\hline & & Cratogeomys tylorhinus & 1 & & & 1 & & & & & & & & & \\
\hline & & Heterogeomys hispidus & 1 & & & 1 & & & & & & & & & \\
\hline & & Heteromys desmarestianus & 1 & & & 1 & & & & & & & & & \\
\hline & & Liomys irroratus & 1 & & & 1 & & & & & & & & & \\
\hline & & Orthogeomys grandis & 3 & & & 3 & & & & & & & & & \\
\hline & & Pappogeomys bulleri & 2 & & & 2 & & & & & & & & & \\
\hline & & Thomomys umbrinus & 4 & & & 4 & & & & & & & & & \\
\hline & & *Zygogeomys trichopus & 1 & & & 1 & $P$ & & & & & & & & \\
\hline & Heterom & nyidae & & & & & & & & & & & & & \\
\hline & & Chaetodipus eremicus & 1 & & & 1 & & & & & & & & & \\
\hline & & Chaetodipus hispidus & 4 & & & 4 & & & & & & & & & \\
\hline
\end{tabular}

